Cover: Photograph showing Upper Klamath Lake, Oregon in July with a cyanobacterial bloom. Photograph taken from Modoc Rim on the eastern shore looking to the northwest. Photograph from U.S. Geological Survey. 


\section{Juvenile Lost River and Shortnose Sucker Year Class Strength, Survival, and Growth in Upper Klamath Lake, Oregon, and Clear Lake Reservoir, California-2016 Monitoring Report}

By Summer M. Burdick, Carl O. Ostberg, and Marshal S. Hoy

Open-File Report 2018-1066 


\section{U.S. Department of the Interior \\ RYAN K. ZINKE, Secretary}

\section{U.S. Geological Survey \\ William H. Werkheiser, Deputy Director \\ exercising the authority of the Director}

U.S. Geological Survey, Reston, Virginia: 2018

For more information on the USGS-the Federal source for science about the Earth, its natural and living resources, natural hazards, and the environment-visit https://www.usgs.gov/ or call 1-888-ASK-USGS (1-888-275-8747).

For an overview of USGS information products, including maps, imagery, and publications, visit https://store.usgs.gov.

Any use of trade, firm, or product names is for descriptive purposes only and does not imply endorsement by the U.S. Government.

Although this information product, for the most part, is in the public domain, it also may contain copyrighted materials as noted in the text. Permission to reproduce copyrighted items must be secured from the copyright owner.

Suggested citation:

Burdick, S.M., Ostberg, C.O., and Hoy, M.S., 2018, Juvenile Lost River and shortnose sucker year class strength, survival, and growth in Upper Klamath Lake, Oregon, and Clear Lake Reservoir, California-2016 Monitoring Report: U.S. Geological Survey Open-File Report 2018-1066, 43 p., https://doi.org/10.3133/ofr20181066.

ISSN 2331-1258 (online) 


\section{Contents}

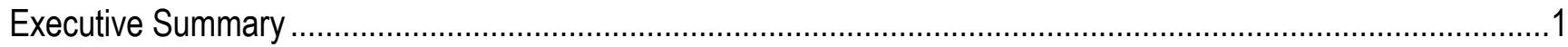

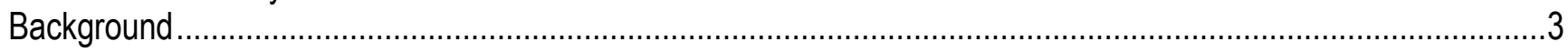

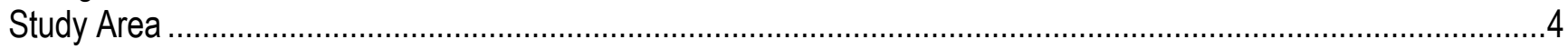

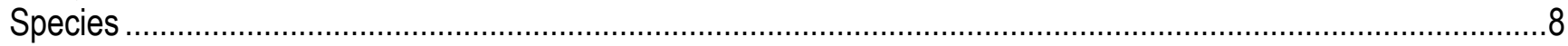

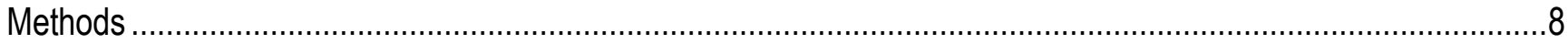

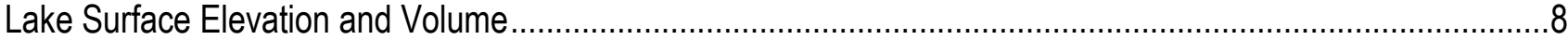

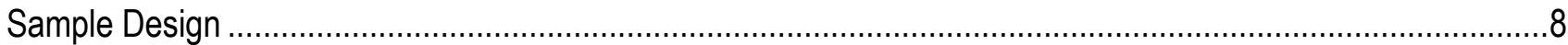

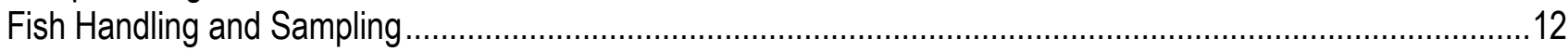

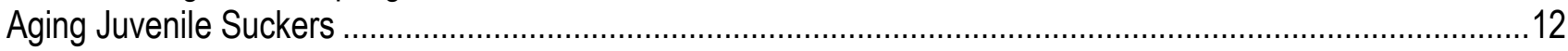

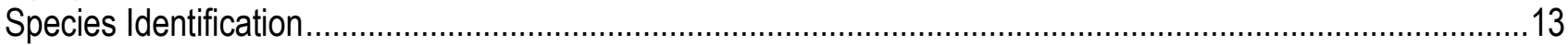

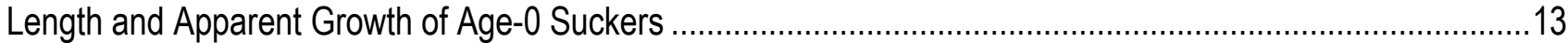

Indices of Juvenile Sucker Year Class Strength and Survival ................................................................15

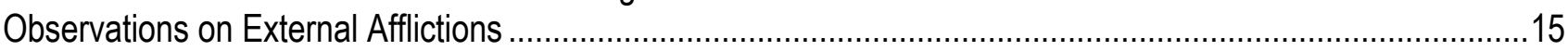

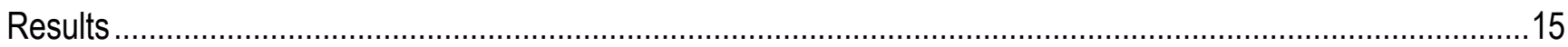

Lake Surface Elevations and Capacity …………...............................................................................

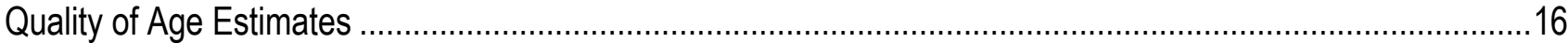

Sucker Taxa Composition, Age, and Length in Fixed and Randomly Determined Sites..................................18

Sucker Taxa and Age Composition .................................................................................................22

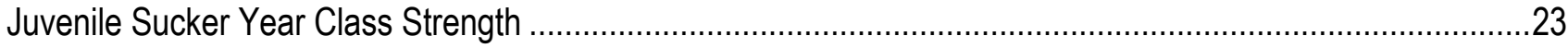

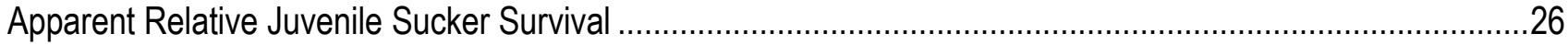

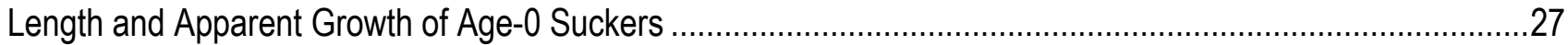

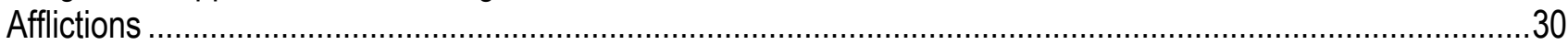

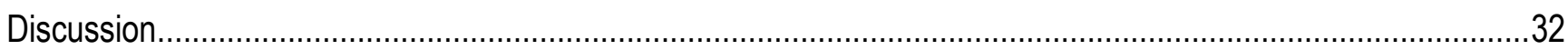

Upper Klamath Lake Year Class Strength ..........................................................................................

Upper Klamath Lake Indices of Age-0 Sucker Survival ...........................................................................3

Clear Lake Sucker Year Class Strength and Formation ........................................................................33

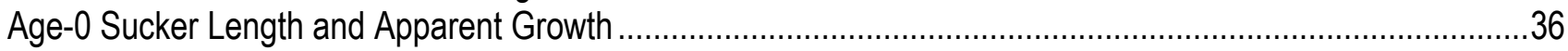

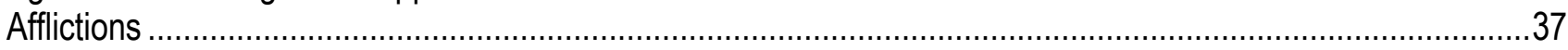

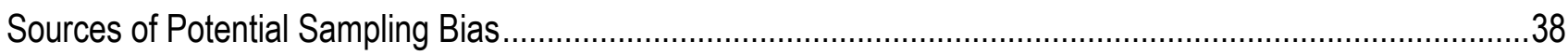

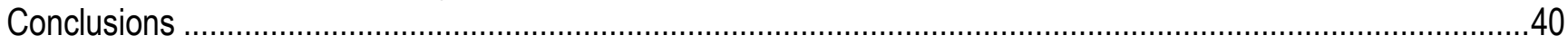

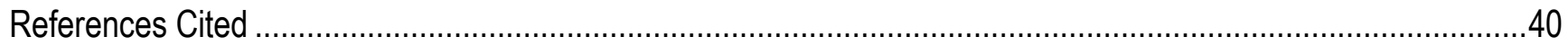

\section{Figures}

Figure 1. Locations of sample sites used to capture juvenile suckers in Upper Klamath Lake,

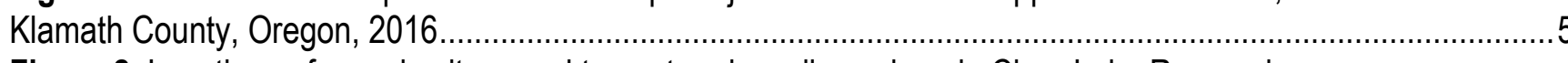

Figure 2. Locations of sample sites used to capture juvenile suckers in Clear Lake Reservoir,

Modoc County, California, 2016

Figure 3. Capacity and surface elevations in Clear Lake, California, and Upper Klamath Lake, Oregon, in 2015 and 2016

Figure 4. Comparison of fin ray annuli counts by two readers for each fin ray for suckers captured in Upper

Klamath Lake, Oregon, and Clear Lake, California, 2016

Figure 5. Number of annuli on suckers collected at fixed and randomly determined sample sites in western and eastern lobes of Clear Lake, California, and in Upper Klamath Lake, Oregon, 2016

Figure 6. Probability of taxa assignment at fixed and randomly determined sites in the eastern and western lobes of Clear Lake Reservoir, California, and Upper Klamath Lake, Oregon, 2016.

Figure 7. Standard lengths of age-0 suckers collected at fixed and randomly determined locations in western and eastern lobes of Clear Lake, California, and in Upper Klamath Lake, Oregon, 2016 
Figure 8. Boxplot of standard lengths for age-0 suckers captured in August 2016 captured in Upper Klamath Lake, Oregon, and Clear Lake, California ..

Figure 9. Probability of taxa assignment as a Lost River sucker versus standard

length for age-0 suckers captured in Upper Klamath Lake, Oregon, August 2015 and 2016.

Figure 10. Lake surface elevations, Clear Lake Reservoir, California, 2011-15

\section{Tables}

Table 1. Number of nets fished for juvenile suckers by area and sampling period in Upper Klamath Lake, Oregon, 2016

Table 2. Number of nets fished for juvenile suckers by area and sampling period in Clear Lake Reservoir,

California, 2016.

Table 3. Numbers of suckers captured, aged using fin rays, and identified to species using genetics from Clear Lake Reservoir, California and Upper Klamath Lake, Oregon, 2016

Table 4. Catch Statistics for fixed and randomly determined sample sites in Clear Lake

Reservoir, California, and Upper Klamath Lake, Oregon, 2016

Table 5. Catch per net and percent of age-0 suckers for each taxa captured in Clear Lake

Reservoir, California and Upper Klamath Lake, Oregon in 2016.

Table 6. Catch statistics for the 2015 cohorts of suckers from Upper Klamath Lake, Oregon. ............................24

Table 7. Catch statistics for 2016 cohorts of suckers from Upper Klamath Lake, Oregon.

Table 8. Catch statistics for the 2016 cohorts of suckers from eastern and western lobes of

Clear Lake Reservoir, California.

Table 9. Indices of August-September survival for age-0 suckers captured in Upper Klamath

Lake, Oregon, 2015 and 2016.

Table 10. Model selection table for models describing variation in standard length of age-0

suckers captured in Upper Klamath or Clear Lakes in August 2016.

Table 11. Model selection table for models describing variation in standard length of age-0

suckers captured in Upper Klamath Lake in August 2015 and 2016.

Table 12. Mean standard length of age-0 shortnose and Lost River suckers captured in Upper Klamath Lake, Oregon, August 2015 and 2016.

Table 13. Proportions of age-0 suckers with attached Lernaea sp., Upper Klamath Lake, Oregon, 2016 .............30

Table 14. Proportions of age-1 and older suckers with attached Lernaea sp., Upper Klamath Lake, Oregon, 2016 .

Table 15. Proportions of age-0 suckers in each of three taxa that had petechial hemorrhages of the skin, Upper Klamath Lake, Oregon, and Clear Lake Reservoir, California.

Table 16. Proportions of age-0 suckers with deformed opercula, Upper Klamath Lake, Oregon, 


\section{Conversion Factors}

U.S. customary units to International System of Units

\begin{tabular}{|c|c|c|}
\hline Multiply & By & To obtain \\
\hline \multicolumn{3}{|c|}{ Length } \\
\hline inch (in) & 2.54 & centimeter $(\mathrm{cm})$ \\
\hline \multicolumn{3}{|c|}{ International System of Units to U.S. customary units } \\
\hline Multiply & By & To obtain \\
\hline \multicolumn{3}{|c|}{ Length } \\
\hline centimeter $(\mathrm{cm})$ & 0.3937 & inch (in.) \\
\hline millimeter $(\mathrm{mm})$ & 0.03937 & inch (in.) \\
\hline meter (m) & 3.281 & foot $(\mathrm{ft})$ \\
\hline kilometer $(\mathrm{km})$ & 0.6214 & mile (mi) \\
\hline \multicolumn{3}{|c|}{ Area } \\
\hline square millimeter $\left(\mathrm{mm}^{2}\right)$ & 0.00155 & square inch $\left(\mathrm{in}^{2}\right)$ \\
\hline square kilometer $\left(\mathrm{km}^{2}\right)$ & 0.004047 & acre \\
\hline cubic meter $\left(\mathrm{m}^{3}\right)$ & 1,233 & acre-foot (acre-ft) \\
\hline
\end{tabular}

Temperature in degrees Celsius $\left({ }^{\circ} \mathrm{C}\right)$ may be converted to degrees Fahrenheit $\left({ }^{\circ} \mathrm{F}\right)$ as:

$$
{ }^{\circ} \mathrm{F}=\left(1.8 \times{ }^{\circ} \mathrm{C}\right)+32 \text {. }
$$

\section{Datum}

Vertical coordinate information is referenced to the Bureau of Reclamation Vertical Datum.

Elevation, as used in this report, refers to distance above the vertical datum. 
This page is left intentionally blank 


\title{
Juvenile Lost River and Shortnose Sucker Year Class Formation, Survival, and Growth in Upper Klamath Lake, Oregon, and Clear Lake Reservoir, California-2016 Monitoring Report
}

\author{
By Summer M. Burdick, Carl O. Ostberg, and Marshal S. Hoy
}

\section{Executive Summary}

The largest populations of federally endangered Lost River (Deltistes luxatus) and shortnose suckers (Chasmistes brevirostris) exist in Upper Klamath Lake, Oregon, and Clear Lake Reservoir, California. Upper Klamath Lake populations are decreasing because adult mortality, which is relatively low, is not being balanced by recruitment of young adult suckers into known spawning aggregations. Most Upper Klamath Lake juvenile sucker mortality appears to occur within the first year of life. Annual production of juvenile suckers in Clear Lake Reservoir appears to be highly variable and may not occur at all in very dry years. However, juvenile sucker survival is much higher in Clear Lake, with non-trivial numbers of suckers surviving to join spawning aggregations. Long-term monitoring of juvenile sucker populations is needed to (1) determine if there are annual and speciesspecific differences in production, survival, and growth, (2) to identify the season (summer or winter) in which most mortality occurs, and (3) to help identify potential causes of high juvenile sucker mortality, particularly in Upper Klamath Lake.

We initiated an annual juvenile sucker monitoring program in 2015 to track cohorts in 3 months (June, August, and September) annually in Upper Klamath Lake and Clear Lake Reservoir. We tracked annual variability in age-0 sucker apparent production, juvenile sucker apparent survival, and apparent growth. Using genetic markers, we were able to classify suckers as one of three taxa: shortnose or Klamath largescale suckers, Lost River, or suckers with genetic markers of both species (Intermediate Prob[LRS]). Using catch data, we generated taxa-specific indices of year class strength, August-September apparent survival, and overwinter apparent survival. We also examined prevalence and severity of afflictions such as parasites, wounds, and deformities.

Indices of year class strength in Upper Klamath Lake were similar for shortnose suckers in 2015 and 2016, but about twice as high for Lost River suckers and suckers having intermediate Prob[LRS] in 2016 than in 2015. Indices of apparent August-September survival were lower in 2016 (0.41) than in 2015 (1.07) for shortnose suckers and suckers identified as having intermediate Prob [LRS] (0.14 in 2016 and 1.69 in 2015). Indices of apparent August - September survival were similar in 2016 (0.16) and 2015 (0.07) for Lost River suckers. Indices of apparent survival were lower for age0 Lost River suckers than age-0 shortnose suckers in both years. Although samples sizes are small, a declining trend in the ratio of Lost River to shortnose suckers from 28/23 (1.22) as age-0 fish in September of 2015 to 1/9 (0.11) as age-1 fish in June of 2016 is consistent with higher over winter apparent mortality for Lost River suckers than shortnose suckers in Upper Klamath Lake. 
Shortnose sucker year class strength was greater in years with high Willow Creek inflows and Clear Lake surface elevation during the spawning season, indicating that access to spawning habitat was an important contributing factor. In previous sampling, age-0 sucker catch per unit effort (CPUE) was relatively high in 2011 and 2012, moderately high in 2013, and zero in 2014 and 2015. The 2011 and 2012 year classes continued to be detected, but the 2013 year class went undetected for the first time in 2016 . The 2014 year class continued to be undetected in 2016. Three suckers with one annulus each on fin rays were captured in Clear Lake in 2016. Although these fish are potential representatives of the 2015 year class, they were small for their age, indicating they may have hatched in 2016 . Age- 0 shortnose and Lost River suckers were captured in Clear Lake in 2016, indicating new cohorts of both taxa were produced. Moderate to abundant year classes were produced in 2011, 2012, and 2016 when lake surface elevation greater than 1,378.9 m (4,524 ft) during the February-June spawning season. Also in 2011 and 2016, rapid increases in lake-surface elevation indicated potentially high Willow Creek inflows. A somewhat less abundant year class produced in 2012 than in 2011 and 2016 was associated with lower spawning season inflows. The apparently smaller 2013 year class was formed when Willow Creek inflows were apparently low and lake surface never exceeded 1,379.2 m (4,524.9 $\mathrm{ft}$ ). In 2014 and 2015, when year-classes were small or not detected, the Clear Lake surface elevations were at or below 1,378.2 m (4,522 ft), and there was very little spring time Willow Creek inflow.

Age-0 shortnose sucker CPUE in Clear Lake was correlated with seasonal decreases in water volumes in 2016 and could not be used to create indices of August-September survival. Age-0 shortnose sucker catch rates in Clear Lake Reservoir were about seven times less in August than in September. Meanwhile, the water volume in Clear Lake Reservoir declined by about 36 percent between these two sampling periods. Higher September catch rates may have resulted from additional age-0 suckers entering the lake from the river, a concentrating effect of declining water volumes, or both.

Differences in August standard length, apparent growth rates, and the prevalence of abnormalities were consistent with healthier age-0 suckers in Clear Lake Reservoir than in Upper Klamath Lake. Age-0 suckers were larger in August in Clear Lake Reservoir than in Upper Klamath Lake, which may be due to an earlier hatch date, faster growth, or both in Clear Lake Reservoir. Sample sizes were only large enough to compare growth rates of age-0 shortnose suckers from Upper Klamath Lake in 2015 to Clear Lake Reservoir in 2016. Age-0 shortnose suckers grew more between August and September in Clear Lake Reservoir in 2016 than in Upper Klamath Lake in 2015. Petechial hemorrhages of the skin on age-0 suckers were more prevalent in Upper Klamath Lake than in Clear Lake Reservoir in 2016. Deformed opercula, black-spot forming parasites, and infections presumed to be Columnaris sp. were observed on less than 12 percent of suckers from Upper Klamath Lake but were not observed on suckers from Clear Lake Reservoir in 2016. 


\section{Background}

Lost River sucker (Deltistes luxatus) and shortnose sucker (Chasmistes brevirostris) are jointly listed as endangered under the Endangered Species Act (U.S. Fish and Wildlife Service, 1988). Two of the remaining spawning populations of both Lost River sucker and shortnose sucker exist in Upper Klamath Lake (Klamath County, Oregon) and Clear Lake Reservoir (Modoc County, California; hearinafter "Clear Lake") (U.S. Fish and Wildlife Service, 2013). The persistence of Upper Klamath Lake Lost River and shortnose sucker populations is threatened by a prolonged lack of recruitment into adult spawning aggregations (National Research Council, 2004; U.S. Fish and Wildlife Service, 2013). Uncertainty exists regarding the role of recruitment limitation to Clear Lake populations, because year classes appear to recruit intermittently but not infrequently (Hewitt and Hayes, 2013). In Upper Klamath Lake, decreasing catch rates of age- 0 juvenile suckers during August and September in most years, and a lack of age-1 or older juvenile sucker catches, indicate that the lack of recruitment is due to high mortality within the first year of life (Burdick and VanderKooi, 2010). In contrast, a more diverse age distribution of juvenile suckers has been documented in Clear Lake, indicating that juvenile sucker survival may be greater in Clear Lake than in Upper Klamath Lake (Burdick, Elliott, and others, 2015).

Recovery of Lost River and shortnose sucker populations requires increasing the numbers of suckers surviving to maturity. A long-term monitoring program exists for adult suckers at spawning areas aimed at tracking recruitment into the spawning populations in Upper Klamath Lake and Clear Lake (Hewitt and others, 2015). This adult sucker monitoring program has not detected substantial recruitment into Upper Klamath Lake spawning populations, as would be expected 4-7 years after suckers hatch. For example, a relatively strong cohort of age- 0 suckers was detected in Upper Klamath Lake by Simon and others (2013) and U.S. Geological Survey (USGS) programs in 2006; this cohort has yet to be detected in spawning populations as of the writing of this report (Hewitt and others, 2015; Burdick and Martin, 2017; D. Hewitt, U.S. Geological Survey, oral commun., 2017). These separate juvenile sucker monitoring programs indicated that substantial numbers of individuals from the 2006 cohort did not persist in Upper Klamath Lake to the age of 2 (Simon and others, 2013; Burdick and Martin, 2017). Causes of high apparent juvenile mortality are still unknown. To help determine the causes and timing of juvenile sucker mortality and to monitor the long-term success of recovery actions, the U.S. Fish and Wildlife Service (2013) prioritized the assessment and monitoring of juvenile sucker populations in Upper Klamath Lake and Clear Lake (Recovery Actions 6.1 and 6.2).

Over the last 2 decades, research and monitoring data have been collected on juvenile Lost River and shortnose suckers in Upper Klamath Lake. Juvenile suckers in Upper Klamath Lake were consistently monitored by Simon and others (2013) from 1997 to 2012. The USGS conducted various research projects from 2001 to 2010 and from 2012 to 2015 with the objective of understanding habitat use, distribution, and health of age- 0 and age- 1 juvenile suckers. Simon and others (2013) sampled with beach seines, cast nets, and trawls using a consistent study design among years, but captured small numbers of suckers in some years relative to USGS sampling with trap nets. Locations and sampling gears used were inconsistent across USGS research projects, making these data undesirable for monitoring long-term trends (Burdick and Martin, 2017). Nevertheless, USGS analyzed data from projects spanning 15 years to identify patterns in recruitment, survival, and growth of age-0 suckers in Upper Klamath Lake (Burdick and Martin, 2017). Simon and others (2013) dataset indicated that the strongest year classes for both species within the 16 years of their sampling period probably occurred 
before 2001, and during 2011. Relatively strong cohorts for both species also were documented by both Simon and others (2013) and the USGS in 2006 (Burdick and Martin, 2017). Because the Simon and others (2013) and USGS sampling occurred primarily in the summer, overwinter and summer-fall survival could not be assessed with data collected in either sampling program. USGS also cautioned that inconsistencies among years in the types of gear used, sample locations, and timing of sample collection limited inferences that could be made from the historical data.

We initiated a new juvenile sucker monitoring program in 2015 with the intention of generating relative indices of juvenile Lost River and shortnose sucker production, growth, and survival in both Upper Klamath Lake and Clear Lake. This monitoring program aims to track cohorts both within and among years. The sample design used in this monitoring program addresses the issues of inconsistency identified by USGS and uses trap nets which are more efficient in catching suckers than active sampling gears such as cast nets, seines, and trawls. Data are anticipated to be useful for identification of environmental variables affecting annual production and survival of young suckers. The dataset also will be useful for understanding collective effects of recovery actions on production, survival, and growth of juvenile suckers.

\section{Study Area}

Upper Klamath Lake is uniformly shallow, with an average water depth of about $2.6 \mathrm{~m}$ and a surface area of about $305 \mathrm{~km}^{2}$ at full pool (National Research Council, 2004). A 6.4-9.5-m-deep trench runs along the western shore of the lake. Most of the flow enters through the Williamson River on the eastern shore and the smaller Wood River to the north (fig. 1). A small but notable amount of water also upwells through the volcanic soils along the lakeshore and falls on the surface of the lake as precipitation. A natural volcanic reef at the outlet of the lake was replaced with a dam in 1921 to provide access to a greater volume of water for agriculture (National Research Council, 2004). The dam allows the lake-surface elevation to range from about 1,261.0 (4,137 ft) to $1,262.8 \mathrm{~m}(4,143 \mathrm{ft}$; https://nwis.waterdata.usgs.gov/nwis/inventory/?site_no=11507001\&agency_cd=USGS\&amp;).

Surface and groundwater inputs exceed flows out of the dam from about October to about June each year, causing the lake volume to increase. Agricultural water deliveries, down-river water releases to meet instream flow requirements, and to a lesser extent evaporation, exceed water inputs from around June to October each year, causing the lake volume to decrease at a somewhat predictable rate. In 67 percent of the years on record (1974-2016), natural inflows replaced water withdrawals the previous spring, such that the lake was at its maximum holding capacity in June (https://nwis.waterdata.usgs.gov/nwis/inventory/?site_no=11507001\&agency_cd=USGS\&amp;).

The bottom of Upper Klamath Lake is covered with fine organic detritus composed primarily of decaying diatoms and cyanobacteria. Shoreline wetlands in the northern part of the lake are heavily vegetated with wocus (Nuphar sp.), tules (Schoenoplectus acutus), and willows (Salix sp.). Spring-fed creeks enter the lake in the area of these wetlands and are associated with relatively good summertime water quality when compared to the rest of the lake (Banish and others, 2009). Massive annual blooms of the blue-green cyanobacterium Aphanizomenon flos-aquae (AFA) drive summer water-quality dynamics in Upper Klamath Lake. Summer water-quality conditions can be extreme: water temperatures $>24^{\circ} \mathrm{C}$, dissolved-oxygen $<2 \mathrm{mg} / \mathrm{L}, \mathrm{pH} \geq 10$, and microcystin toxin concentrations 40-60 ppb (Eldridge, Caldwell Eldridge and others, 2012; Eldridge, Wood, and Echols, 2012). 


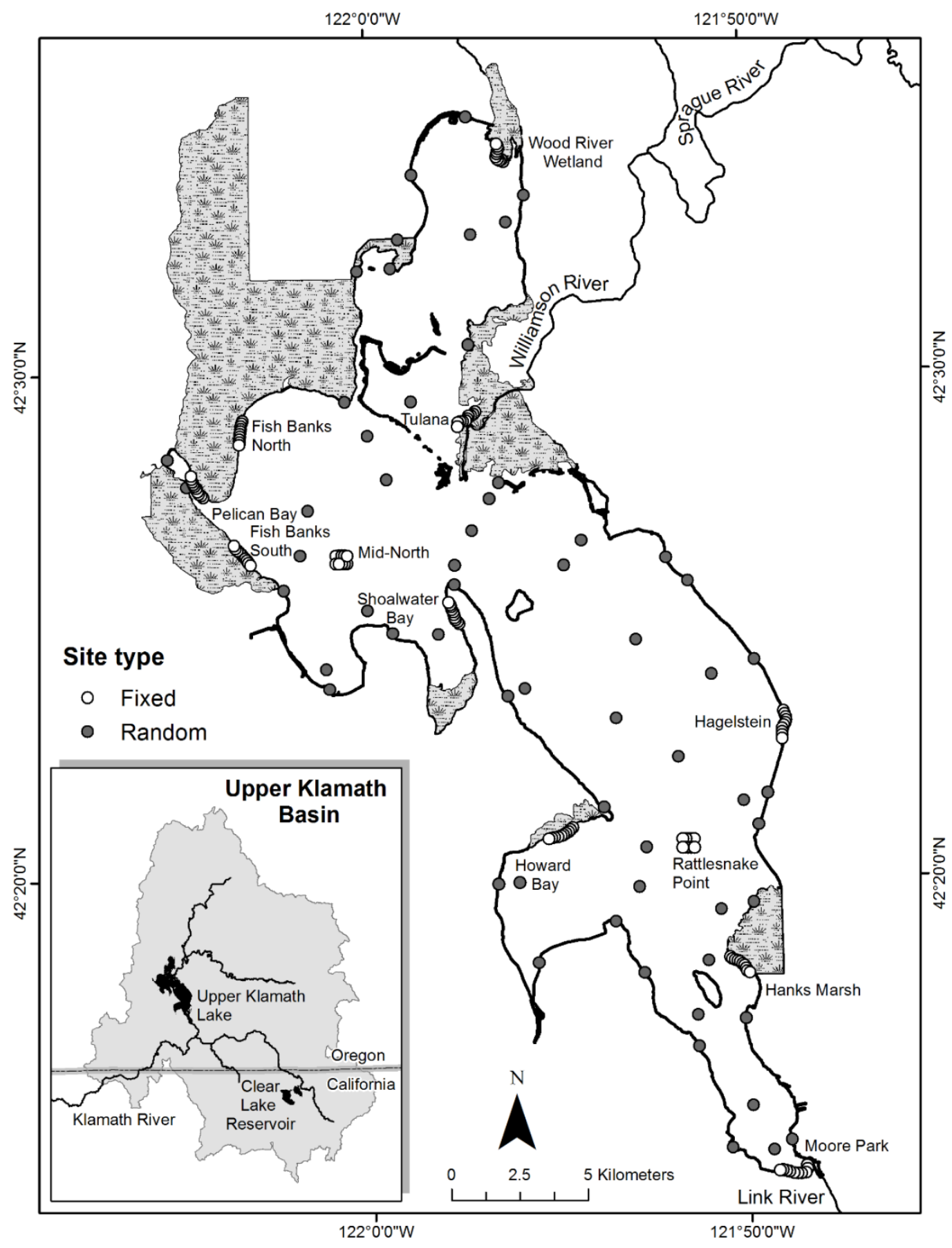

Figure 1. Locations of sample sites used to capture juvenile suckers in Upper Klamath Lake, Klamath County, Oregon, 2016. 
Clear Lake, located in the upper Lost River watershed, was historically a natural lake covering about 6,500 ha (fig. 2). An associated wetland and meadow was located to the east of the lake. The Bureau of Reclamation built a dam on the Lost River near the lake outlet in 1910 to enable better seasonal water regulation. The dam enlarged the lake and inundates the wetland in most years which expands the lake by about 3,900 ha (Buettner and Scoppettone, 1991). The present day Clear Lake has two distinct parts that are connected by a wide shallow channel; the shallower former marsh on the eastern side and the deeper historic lake on the western side. Willow Creek, which has the only known spawning area and provides the only substantial inflows, enters into the eastern lobe of the reservoir near the dam. Inflows primarily occur in the winter or spring and the tributaries become intermittent in mid-summer. Water is released through the Clear Lake Dam into the Lost River to provide spring and summer irrigation to the Langell Valley in Oregon. At a lake surface elevation of about 1,378.6 m $(4,523 \mathrm{ft})$, the two parts of the lake become disconnected. At lake-surface elevations around 1,378.9 m $(4,524 \mathrm{ft})$, access to Willow Creek is impeded for spawning suckers (National Marine Fisheries Service and U.S. Fish and Wildlife Service, 2013). Water can be delivered down river below the point of disconnection between the lobes until the lake surface elevation reaches the operational floor at $1,378.3 \mathrm{~m}(4,522 \mathrm{ft})$. The eastern lobe almost completely dries out when the lake surface elevation declines to about 1,377.7 m (4,520 ft), which happened in 2014 and 2015. Due to these dynamics, the lake depth can fluctuate by more than $3 \mathrm{~m}$ among and within years (https://www.usbr.gov/pnbin/arcread.pl?station=CLK).

Clear Lake is in the U.S. Fish and Wildlife Service's Clear Lake National Wildlife Refuge, and the upper watershed is almost entirely located within the U.S. Forest Service's Modoc and Fremont National Forests. The area around the lake is rocky with sagebrush (Artemesia sp.) steppe plant communities and western juniper (Juniperus occidentalis), whereas the upper watershed is a ponderosa pine (Pinus ponderosa) forest (Buettner and Scoppettone, 1991). The bottom of Clear Lake is covered with claylike sediment and occasional large lava rocks. The lake is turbid, which is likely the result of wind coupled with shallow water and fine sediments. Summer water temperatures have greater diel fluctuations and water-quality is generally better than in Upper Klamath Lake: water temperatures up to $26^{\circ} \mathrm{C}$, dissolved-oxygen $\geq 5 \mathrm{mg} / \mathrm{L}, \mathrm{pH}$ around 8.5 , and no detectable microcystin toxin (Burdick, Elliott, and others, 2015). 


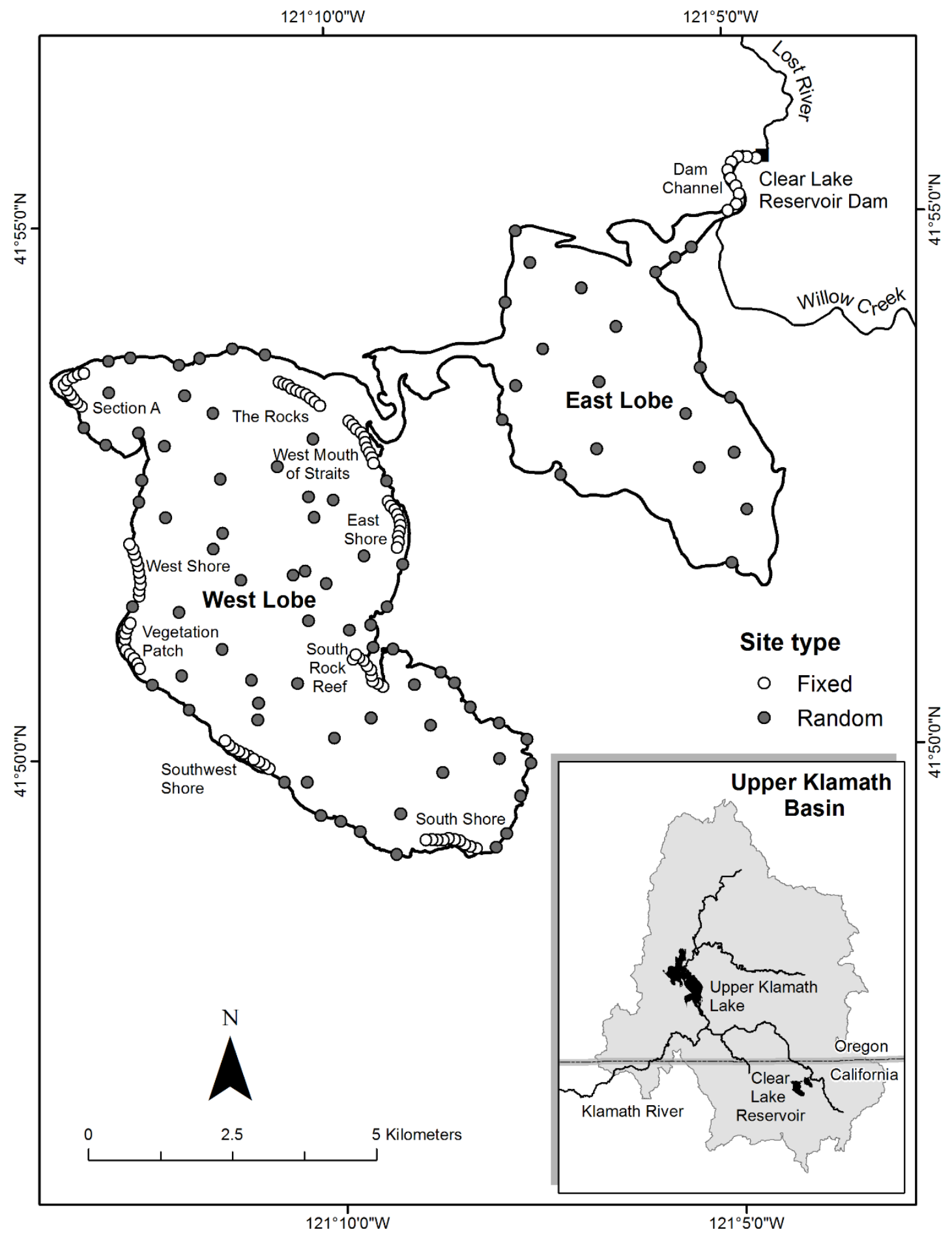

Figure 2. Locations of sample sites used to capture juvenile suckers in Clear Lake Reservoir, Modoc County, California, 2016. 


\section{Species}

Lost River and shortnose suckers are long-lived lake-dwelling catostomids that make springtime spawning migrations to lake shore or tributaries beginning at about 4-7 years of age (Hewitt and others, 2015). Upper Klamath Lake populations typically spawn from March to June, whereas Clear Lake populations spawn from February to April (Hewitt and Hayes, 2013; Burdick, Hewitt, and others, 2015). Spawning migrations start when spawning tributary water temperatures exceed $10{ }^{\circ} \mathrm{C}$ in Upper Klamath Lake and about $6{ }^{\circ} \mathrm{C}$ in Clear Lake. Larvae of Upper Klamath Lake river spawning populations out-migrate at night in May and early June to in-lake rearing habitats within several days of emerging from gravel (Cooperman and Markle, 2003). Clear Lake sucker larvae out-migrate from Willow Creek in the spring probably beginning in early April and into May (Sutphin and Tyler, 2016). Age-0 juvenile suckers of both taxa are widely distributed throughout Upper Klamath Lake in late-July and August, and there is no evidence of directed migrations during that time (Hendrixson and others, 2007; Burdick and others, 2009; Burdick and Hewitt, 2012). Age-1 suckers are much less abundant than age-0 suckers, and immature suckers age- 2 and older are rarely encountered in Upper Klamath Lake. A wide age-range of juvenile suckers can be found throughout Clear Lake from June to September (Burdick and Rasmussen, 2013).

\section{Methods}

\section{Lake Surface Elevation and Volume}

We summarized surface elevations and water volumes for both Upper Klamath Lake and Clear Lake to provide context relative to annual and seasonal water availability. Lake-surface elevation data for Upper Klamath Lake was acquired from the National Water Information System (https://nwis.waterdata.usgs.gov/nwis/uv/?site_no=11507001\&agency_cd=USGS\&amp;referred_mod $\mathrm{ule}=\mathrm{sw})$. We used data for virtual site 11507001 , which gives a weighted mean average of three physical locations within Upper Klamath Lake. Upper Klamath Lake volumes were estimated based on lake surface elevation and area capacity data provided by the Bureau of Reclamation (M. Skinner, oral commun., November 16, 2017). Clear Lake surface elevation and volume data were acquired from the Bureau of Reclamation (https://www.usbr.gov/pn-bin/arcread.pl?station=CLK). All surface elevations are based on the Bureau of Reclamation's vertical datum for the Upper Klamath Basin.

\section{Sample Design}

We sampled for suckers with trap nets to assess species-specific annual variability in production and growth and annual and seasonal variability in survival of juvenile suckers in Upper Klamath and Clear Lakes. The timing of the three sampling periods was chosen based on previous catch data in Upper Klamath Lake. Specifically, we targeted age-1 suckers in early June, the peak of age-0 sucker catches in early August, and the tail end of age-0 sucker catches in late September (Burdick and Martin, 2017). Sample periods were paired so that Upper Klamath and Clear Lakes were sampled for 1 week in each of the 3 months. An evaluation of the study design in 2015 indicated that with increased effort concentrated into shorter time periods, we could better describe differences in catch rates between sampling periods. In 2015, we set 59 to 118 nets in each lake in each of June, August, and September (Burdick and others, 2016). In 2016, we set 93 to 116 nets in each of the lakes in each of June, August, and September (tables 1 and 2). Samples were spread out over 3 weeks within each month in 2015 and concentrated into 1 week per month in 2016 by employing a second team to fish concurrently. 
To reduce potential sample bias caused by apparently minor spatial heterogeneity in the densities, species, ages, sizes or health of suckers, we selected fixed sample sites in a variety of habitats throughout both lakes (Burdick and others, 2008; Burdick and Hewitt, 2012). Age-0 suckers at least $45 \mathrm{~mm}$ standard length (SL), the size targeted in our sampling, are not known to be distributed differentially within Upper Klamath Lake based on species or size (Hendrixson and others, 2007; Burdick and Brown, 2010; Burdick and Hewitt, 2012). However, age-1 suckers are more likely to be found in shallow $(<1 \mathrm{~m}$ deep) near-shore habitats in the spring and deep water around $2 \mathrm{~m}$ deep in the summer (Bottcher and Burdick, 2010). Spatial patterns among age classes of suckers have not been identified in Clear Lake (Burdick and Rasmussen, 2012). We sampled at 10 fixed shoreline sample areas in each lake in 2015. In 2016, we added two fixed sample areas in Upper Klamath Lake (one at Mid-North and one at Rattlesnake Point) to further account for potential differences in near and offshore juvenile sucker population composition. Sample areas were either 1-km-long sections of shoreline or $300 \mathrm{~m}^{2}$ offshore areas. Within each area, 10 fixed sites were identified as potentially accessible given a variety of water levels. In 2015, 5 or 6 of the 10 predetermined sites in each fixed area were sampled in June and September, and all 10 were sampled in August (Burdick and others, 2016). In 2016, 8 of 10 sites at each area in Upper Klamath Lake and 7 of 10 sites in each area in Clear Lake were sampled during each sampling period (tables 1 and 2$)$. Shallow water $(<0.4 \mathrm{~m})$ prevented access to some sample areas in September of both years, which is reflected in the numbers of nets fished (tables 1 and 2; Burdick and others, 2016).

To check for inadvertent bias in our fixed-site selection, we also selected new randomly determined site locations in 2016 for comparison with fixed sites (tables 1 and 2; Burdick and others, 2016). Randomly determined site locations were evenly allocated between near-shore $(<100 \mathrm{~m}$ from shore) and offshore ( $\geq 500 \mathrm{~m}$ from shore). We compared the percentages of nets to catch one or more age- 0 suckers, the mean non-zero catch, and SLs of suckers between fixed and randomly determine site locations. We also examined the age distribution by taxa.

To examine inadvertent bias due to the seasonal timing of sampling, we discuss additional data collected using the same gear and methods at other times in 2016 for another project. A total of 10 nets each were set at Mid-North, Fish Banks South, and Fish Banks North in Upper Klamath Lake from July 25 to July 28, 2016 (fig. 1) as part of a separate research project. We summarize catch statistics from these net sets to discuss the possibility of peak age- 0 sucker catches occurring earlier than during our primary sampling. These July data are not included in year-class strength, survival, or growth analyses. 
Table 1. Number of nets fished for juvenile suckers by area and sampling period in Upper Klamath Lake, Oregon, 2016.

[Area locations are shown in figure 1. Seasons were designated based on timing of seasonal peaks in historical catches of age-1 suckers in June, age- 0 suckers in August, and low catches of both age classes in September. Two nets at the Wood River Wetland and one at the Shoalwater Bay site failed to fish properly and were excluded from this table. Latitude/Longitude coordinates for the mid-point of each area based on North American Datum of 1983]

\begin{tabular}{|c|c|c|c|c|c|c|}
\hline \multirow{2}{*}{ Area } & \multirow{2}{*}{ Latitude } & \multirow{2}{*}{ Longitude } & \multirow{2}{*}{ Habitat description } & \multicolumn{3}{|c|}{ Number of nets fished } \\
\hline & & & & June 20-24 & August 8-11 & September 19-22 \\
\hline Wood River Wetland & $42^{\circ} 34^{\prime} 18.84^{\prime \prime} \mathrm{N}$ & $121^{\circ} 56^{\prime} 27.44^{\prime \prime} \mathrm{W}$ & River mouth & 8 & 6 & ${ }^{1} 0$ \\
\hline Fish Banks North & $42^{\circ} 28^{\prime} 53.18^{\prime \prime} \mathrm{N}$ & $122^{\circ} 3^{\prime} 22.89^{\prime \prime} \mathrm{W}$ & Submergent vegetation & 8 & 8 & 8 \\
\hline Fish Banks South & $42^{\circ} 26^{\prime} 25.19^{\prime \prime} \mathrm{N}$ & $122^{\circ} 3^{\prime} 20.45^{\prime \prime} \mathrm{W}$ & Submergent vegetation & 8 & 8 & 8 \\
\hline Pelican Bay & $42^{\circ} 27^{\prime} 48.44^{\prime \prime} \mathrm{N}$ & $122^{\circ} 4^{\prime} 37.62^{\prime \prime} \mathrm{W}$ & Submergent vegetation & 8 & 8 & 8 \\
\hline Tulana & $42^{\circ} 29^{\prime} 5.56^{\prime \prime} \mathrm{N}$ & $121^{\circ} 57^{\prime} 19.40^{\prime \prime} \mathrm{W}$ & Restored shallow (1-2 m) water lake & 8 & 8 & ${ }^{1} 0$ \\
\hline Shoalwater Bay & $42^{\circ} 25^{\prime} 16.54^{\prime \prime} \mathrm{N}$ & $121^{\circ} 57^{\prime} 45.27^{\prime \prime} \mathrm{W}$ & Deep $(4-5 \mathrm{~m})$ water with rocky shoreline & 7 & 8 & 8 \\
\hline Hagelstein (in lake) & $42^{\circ} 23^{\prime} 0.79^{\prime \prime} \mathrm{N}$ & $121^{\circ} 48^{\prime} 56.44^{\prime \prime} \mathrm{W}$ & Shallow (1-2) water with rocky shoreline & 8 & 8 & 8 \\
\hline Howard Bay & $42^{\circ} 20^{\prime} 49.72^{\prime \prime} \mathrm{N}$ & $121^{\circ} 54^{\prime} 57.38^{\prime \prime} \mathrm{W}$ & Emergent vegetation & 8 & 8 & 8 \\
\hline Hanks Marsh & $42^{\circ} 18^{\prime} 17.85^{\prime \prime} \mathrm{N}$ & $121^{\circ} 50^{\prime} 13.72^{\prime \prime} \mathrm{W}$ & Emergent vegetation & 8 & 8 & 8 \\
\hline Moore Park & $42^{\circ} 14^{\prime} 6.57^{\prime \prime} \mathrm{N}$ & $121^{\circ} 48^{\prime} 46.31^{\prime \prime} \mathrm{W}$ & Boulders and large wood along shoreline & 8 & 8 & 8 \\
\hline Mid-North & $42^{\circ} 26^{\prime} 0.91^{\prime \prime} \mathrm{N}$ & $122^{\circ} 0^{\prime} 56.35^{\prime \prime} \mathrm{W}$ & Open water offshore & 8 & 8 & 8 \\
\hline Rattlesnake Point & $42^{\circ} 20^{\prime} 34.57^{\prime \prime} \mathrm{N}$ & $121^{\circ} 51^{\prime} 3.79 " \mathrm{~W}$ & Open water offshore & 8 & 8 & 8 \\
\hline Random & Various & Various & Various & 20 & 20 & 27 \\
\hline Total net sets & & & & 115 & 114 & 107 \\
\hline
\end{tabular}

${ }^{1}$ Too shallow to sample in September. 
Table 2. Number of nets fished for juvenile suckers by area and sampling period in Clear Lake Reservoir, California, 2016.

[Area locations are shown in figure 2. Seasons were designated based on timing of seasonal peaks in historic catches of age-1 suckers in June, age-0 suckers in August, and low catches of both age classes in September in Upper Klamath Lake, Oregon. Seasonal timing of samples was based on Upper Klamath Lake because there was no data from Clear Lake to use as a baseline. One net failed in September at the West Mouth of the Straits and was not included in this table. Latitude/Longitude coordinates for the mid-point of each area based on North American Datum of 1983]

\begin{tabular}{|c|c|c|c|c|c|c|}
\hline \multirow[b]{2}{*}{ Area } & \multirow[b]{2}{*}{ Latitude } & \multirow[b]{2}{*}{ Longitude } & \multirow[b]{2}{*}{ Habitat description } & \multicolumn{3}{|c|}{ Number of nets fished } \\
\hline & & & & June 6-10 & August 1-4 & $\begin{array}{c}\text { September 12- } \\
15 \\
\end{array}$ \\
\hline $\begin{array}{l}\text { Dam to Willow Creek } \\
\text { mouth (Dam Channel) }\end{array}$ & $41^{\circ} 55^{\prime} 24.80^{\prime \prime} \mathrm{N}$ & $121^{\circ} 4^{\prime} 56.75^{\prime \prime} \mathrm{W}$ & Deep to shallow, dredged channel & 7 & 7 & 7 \\
\hline The Rocks & $41^{\circ} 53^{\prime} 25.75^{\prime \prime} \mathrm{N}$ & $121^{\circ} 10^{\prime} 26.15^{\prime \prime} \mathrm{W}$ & Rocky shoreline & 7 & 7 & 7 \\
\hline West Mouth of Straits & $41^{\circ} 52^{\prime} 58.76^{\prime \prime} \mathrm{N}$ & $121^{\circ} 9^{\prime} 35.24^{\prime \prime} \mathrm{W}$ & Shallow with clay substrate & 7 & 7 & 6 \\
\hline Section A & $41^{\circ} 53^{\prime} 31.72^{\prime \prime} \mathrm{N}$ & $121^{\circ} 13^{\prime} 21.14^{\prime \prime} \mathrm{W}$ & $\begin{array}{l}\text { Shallow with clay substrate and } \\
\text { gravel shoal }\end{array}$ & 7 & 7 & 7 \\
\hline West Shore & $41^{\circ} 51^{\prime} 48.77^{\prime \prime} \mathrm{N}$ & $121^{\circ} 12^{\prime} 28.12^{\prime \prime} \mathrm{W}$ & Over $1 \mathrm{~m}$ deep, clay substrate & 7 & 7 & 7 \\
\hline East Shore & $41^{\circ} 52^{\prime} 11.56^{\prime \prime} \mathrm{N}$ & $121^{\circ} 9^{\prime} 10.31^{\prime \prime} \mathrm{W}$ & Rocky & 7 & 7 & 7 \\
\hline Vegetation Patch & $41^{\circ} 51^{\prime} 4.47^{\prime \prime} \mathrm{N}$ & $121^{\circ} 12^{\prime} 40.10^{\prime \prime} \mathrm{W}$ & Shallow with submergent vegetation & 7 & 7 & 7 \\
\hline South Rock Reef & $41^{\circ} 50^{\prime} 47.41^{\prime \prime} \mathrm{N}$ & $121^{\circ} 9^{\prime} 34.39^{\prime \prime} \mathrm{W}$ & Rocky with clay around rocks & 7 & 7 & 7 \\
\hline South Shore & $41^{\circ} 49^{\prime} 11.02^{\prime \prime} \mathrm{N}$ & $121^{\circ} 8^{\prime} 34.03^{\prime \prime} \mathrm{W}$ & Shallow with clay substrate & 7 & 7 & 7 \\
\hline Southwest Shore & $41^{\circ} 50^{\prime} 0.46^{\prime \prime} \mathrm{N}$ & $121^{\circ} 11^{\prime} 7.77^{\prime \prime} \mathrm{W}$ & Shallow with clay substrate & 7 & 7 & 7 \\
\hline Random East Lobe & Various & Various & Various & 7 & 7 & ${ }^{1} 0$ \\
\hline Random West Lobe & Various & Various & Various & 21 & 23 & 23 \\
\hline Total net sets & & & & 98 & 100 & 92 \\
\hline
\end{tabular}

${ }^{1}$ Too shallow to sample in September 


\section{Fish Handling and Sampling}

Suckers were sampled with rectangular trap nets with mouth dimensions of $0.61 \times 0.91 \mathrm{~m}$, a 10-m-lead, and three internal fykes. Captured suckers were enumerated and measured to SL. The leading left pectoral fin ray was removed for aging suckers. Due to large numbers of suckers captured in 2016, fin rays were not collected from small suckers (19-89 mm SL) from Upper Klamath Lake that were presumed to be age-0 fish based on length at date of capture (Burdick and Martin, 2017). We compared the length and number of annuli on fish with fin rays collected to length of suckers without fin rays collected to validate our length-based age assumptions. Fin rays from three suckers collected from Clear Lake were lost or damaged and therefore not included in analysis. A small (about $2 \mathrm{~mm}^{2}$ ) piece of tissue from the caudal fin was collected for genetic identification to taxa. The numbers of suckers from which age and genetic samples were collected and analyzed are given in table 3. Emaciation, deformities, macro parasites, petechial skin hemorrhaging, and gill abnormalities were systematically recorded. Other abnormalities and afflictions were noted when they were observed. Suckers were released at their site of capture or sacrificed for other research.

Table 3. Numbers of suckers captured, aged using fin rays, and identified to species using genetics from Clear Lake Reservoir, California and Upper Klamath Lake, Oregon, 2016.

[The numbers of juveniles less than or equal to 300 millimeters standard length, the approximate size at which shortnose suckers reach maturity, are given]

\begin{tabular}{llc}
\hline \multicolumn{1}{c}{ Number of suckers } & $\begin{array}{c}\text { Clear } \\
\text { Lake } \\
\text { Reservoir }\end{array}$ & $\begin{array}{c}\text { Upper } \\
\text { Klamath } \\
\text { Lake }\end{array}$ \\
\hline Aged with fin rays & 247 & 211 \\
Genetic identification & 192 & 301 \\
Captured and measured & 250 & 313 \\
\hline
\end{tabular}

\section{Aging Juvenile Suckers}

To estimate fish age, fin rays were mounted in epoxy, sectioned, and viewed by two experienced readers under magnification using transmitted light (Quist and others, 2012). The number of annuli was first determined in blind reads, with each reader having no knowledge of the other's annuli count. The differences between annuli counts of the same structures were summarized to examine aging precision. When both readers agreed on a number of annuli, that number was presumed to be the correct age and was used in analyses. If the original two readers disagreed by more than two annuli, the fin ray data was excluded from analysis. If there was disagreement in the annuli count of no more than two, the two readers viewed the structure together and came to a consensus or a third reader acted as a tie breaker. 


\section{Species Identification}

To identify juvenile suckers to taxa, we applied genetic identification methods described by Hoy and Ostberg (2015). Caudal fin tissue was collected and dried from all juvenile suckers. Deoxyribonucleic acid (DNA) was extracted from the caudal tissues using DNeasy kits (Qiagen, Inc. ${ }^{\circledR}$, Valencia, California). A total of 18 nuclear DNA TaqMan ${ }^{\circledR}$ assays were used to differentiate the species based on single nucleotide polymorphisms (SNPs) (Hoy and Ostberg, 2015). A mitochondrial DNA (mtDNA) TaqMan ${ }^{\circledR}$ assay also was applied to identify the maternal lineage (Lost River or shortnose sucker) for each individual (Hoy and Ostberg, 2015).

We used the program STRUCTURE, version 2.3 (Pritchard and others, 2000; Evanno and others, 2005), to probabilistically assign individual multilocus genotypes to the sampled juvenile suckers based on the posterior distribution of the program output. STRUCTURE uses a Markov chain Monte Carlo (MCMC) simulation approach to identify the posterior probability (q) for the proportion of an individual genotype derived from each of $\mathrm{K}$ population clusters. We applied the admixture model with independent allele frequencies, given the high differentiation between Lost River and shortnose suckers. A total of 10 repetitions were run in STRUCTURE, and the model parameters were as follows: (1) markers assumed to be unlinked; (2) 18 nuclear loci; and (3) 50,000 burn-in steps, followed by 100,000 MCMC iterations. We followed the procedure of Evanno and others (2005) to estimate the most probable number of $\mathrm{K}$ population clusters. The most probable number of population clusters was $\mathrm{K}=2$ (that is, Lost River and shortnose suckers). Therefore, admixture proportions between Lost River and shortnose suckers were estimated for each individual using the mean posterior probability over the 10 repetitions.

SNPs available for species identification cannot distinguish shortnose suckers from cooccurring Klamath largescale suckers. Previous studies that used morphological identification indicate that Klamath largescale suckers make less than 10 percent of age-0 juvenile suckers captured in Upper Klamath Lake and Clear Lake (Burdick and others, 2008, 2009; Burdick and Brown, 2010). Throughout this report, we call the group of suckers identified as either shortnose or Klamath largescale suckers shortnose suckers, though we acknowledge they are likely a combination of both shortnose and Klamath largescale suckers.

We analyzed genetic samples from only 493 of 563 captured suckers due to budget constraints. We prioritized analysis of small suckers, because these were the least likely to be correctly identified to species using morphology. However, our sub-set of analyzed samples included a range of sizes of suckers. For data analysis, we categorized suckers having a Prob[LRS] $\geq 0.95$ a Lost River sucker, those with a Prob[LRS] $\leq 0.05$ a shortnose sucker, and fish with a Prob[LRS] intermediate of the two values (Intermediate Prob[LRS]) (Burdick and others, 2016). We used the morphological identification for suckers that had no genetic identification and had a morphological identification, excepting fish that were less than $123 \mathrm{~mm}$ SL (Markle and others, 2005). We chose $123 \mathrm{~mm}$ SL as a cut-off because that is the length above which all of the morphological and genetic identifications were in agreement, when both collected on the same fish. We did not identify 37 suckers from Clear Lake and 12 suckers from Upper Klamath Lake to taxa due to their small size and missing genetic data.

\section{Length and Apparent Growth of Age-0 Suckers}

To determine if mid-summer SL differed between taxa and location, we fit a series of multiple linear regression models to SL data of age-0 suckers captured in August 2016. This analysis was restricted to data collected in 2016 because no age- 0 suckers were captured in Clear Lake in 2015 . We refer to the sub-set of data used in this analysis as the "2016 2-lake data subset." The annual August sampling event was chosen for this analysis because it was the first in which age- 0 suckers were 
captured each year. Our first step in this analysis was to determine the best way to describe taxonomic variation. We did this by comparing two models in which SL was the response variable. In one of these models, taxa was defined as a continuous variable based on the probability of taxa assignment from the STRUCTURE output. In the second model, we used the three categorical classifications of taxa described in the previous section. The most parsimonious model was used to determine which way to describe taxa in other models. We then fit four more descriptive models in which SL was the response variable. This model set included single predictor variable models for taxa (Taxa) and lake (Lake), an additive model that combined predictor variables for taxa and lake (Taxa + Lake), and an interactive model (Taxa*Lake). Models were fit using program $\mathrm{R}$ and the glm function (R Core Team, 2013). We then compared models using the bias-adjusted Akaike information criteria (AICc), which ranks models based on parsimony and includes a small sample size adjustment (Burnham and Anderson, 2002). We present results from the most parsimonious model rather than model averaged results, because the most parsimonious model had overwhelming support.

To determine if SL of age-0 suckers in Upper Klamath Lake varied between August 2015 and 2016 or relative to taxa we used additional data collected in this monitoring program in 2015 (Burdick and others, 2016). This analysis was restricted to Upper Klamath Lake because no age-0 suckers were captured in Clear Lake in 2015. We refer to the sub-set of data used in this analysis as the "Upper Klamath Lake 2-year data sub set." To determine if taxa should be categorically or continuously defined in this 2-year dataset, we repeated the first step in the previous analysis on these data. We then fit a series of general linear models, in which SL was the response variable. Models included single predictor variable models for taxa (Taxa) and year (Year), an additive model that combined predictor variables (Taxa + Year), and an interactive model (Taxa*Year). Models were fit and ranked using program $\mathrm{R}$ as described above. We present results from the most parsimonious model rather than model averaged results because the most parsimonious model had all of the support.

To put August SL of suckers captured in 2016 into a long-term context, we compared to SL data presented in Burdick and others (2017) for suckers captured in Upper Klamath Lake on the same dates in other years. We restricted our comparison to the years 2001-07, in which at least 10 suckers of a given taxa were measured from August 8-11. SLs were considered different among years based on non-overlapping notches calculated at the median $\pm 1.58 / \sqrt{n}$, where $\mathrm{n}$ is the sample size. Chambers and others (1983) found that non-overlapping notches calculated in this manner provided strong evidence of a significant difference in medians.

Our ability to examine within-year growth of age- 0 suckers was limited due to small numbers of juvenile suckers captured in September. Relatively large numbers of age- 0 shortnose suckers captured in September in Upper Klamath Lake in $2015(\mathrm{n}=93)$ and in Clear Lake in $2016(\mathrm{n}=15)$ permitted a limited examination of first year growth. We hypothesized that first year growth would be greater in Clear Lake than in Upper Klamath Lake due to the more mild water-quality in the former (Burdick and others, 2017). Therefore, we used SL data collected for age-0 shortnose suckers in August and September in Upper Klamath Lake in 2015 and Clear Lake in 2016 to examine and compare apparent growth for these two groups of fish. We fit two general linear models where SL was the response variable. In our first model, SL was modeled as an additive function of Lake and Month (Lake + Month). The month parameter described the change in mean SL between August and September, and the lake parameter described a fixed difference in size between the two lakes. In our second model, the variation in SL was an interactive function of lake and month (Lake*Month). This model allowed the change in length between August and September to differ by lake. Based on results from the previous comparison of August SLs between lakes, we assumed there would be a difference in SL between lakes and did not fit a model that excluded a lake parameter. Models were fit and ranked using program $\mathrm{R}$ as described above (R Core Team, 2013). 


\section{Indices of Juvenile Sucker Year Class Strength and Survival}

To describe annual relative (among cohorts, taxa, and lakes) year-class strength and apparent age-0 sucker production, we calculated (1) the proportion of August nets to catch one or more age-0 suckers (successful age-0 nets), (2) the mean August catch per unit effort (CPUE) for age-0 suckers in successful age- 0 nets, and (3) the total August CPUE as the number of suckers in each taxa divided by the number of nets set. Our approach to assessment of age- 0 survival was to compare CPUE by yearclass between sampling periods. Our index of age- 0 summer survival in Upper Klamath Lake was a ratio of September and August total CPUE calculated for each taxa. We also calculated an index of overwinter apparent survival as the ratio of June 2016 and September 2015 total CPUE. We discuss seasonal CPUE in Clear Lake, but because CPUE increased between August and September we did not consider the ratio of seasonal CPUE values an index of within-year survival.

The usefulness of our year-class strength and survival indices depends on the assumption that sampling efficiency was similar between years. The presence of vegetation, substrate type, and water depth have minor effects on detection probability of juvenile suckers (Burdick and others, 2008). By using the same fixed sites and sampling randomly determined sites throughout fairly homogenous habitat with little to no vegetation, we ensured that habitat variables were similar at sampled sites between years. Furthermore, water management in Upper Klamath Lake ensures that water depth is similar each August and therefore did not differentially effect capture probability. Water depth decreases at a similar rate in Upper Klamath Lake between August and September sample periods each year and could cause higher capture probability in September than in August (fig. 3). For this reason, we caution that our survival indices are not actual measures of survival but are useful as relative indices to be compared among years.

\section{Observations on External Afflictions}

We summarized the prevalence and intensity of external afflictions on juvenile suckers as a way to compare the apparent health of suckers between years and lakes. We pay special attention to those afflictions that are either common or potentially associated with mortality (Markle and others, 2014; Burdick, Hewitt, and others, 2015). These included petechial hemorrhaging of the skin, opercular deformities, black spots (presumed to be encysted metacercariae of trematodes), and Lernaea sp.

\section{Results}

\section{Lake Surface Elevations and Capacity}

Higher surface-water inflows in 2016 than in 2015 resulted in different effects on the summertime water volume and depth in each of the two lakes (fig. 3). In Clear Lake, water volumes were greater throughout the summer and declined faster in 2016 than 2015. Clear Lake held 2.8 times as much water on June 1 and 2.4 times as much water on October 1 in 2016 than in 2015. This was a difference of at least 59,000 acre-feet of water between years. Water depth was $1.5 \mathrm{~m}$ deeper on June 1 and $1.0 \mathrm{~m}$ deeper on October 1 in 2016 than in 2015. In contrast, water depth in Upper Klamath Lake was only $0.11 \mathrm{~m}$ higher on June 1, 2016, than for the same date in 2015. Water volume in Upper Klamath Lake declined slightly faster over our sampling season in 2016 than 2015. 


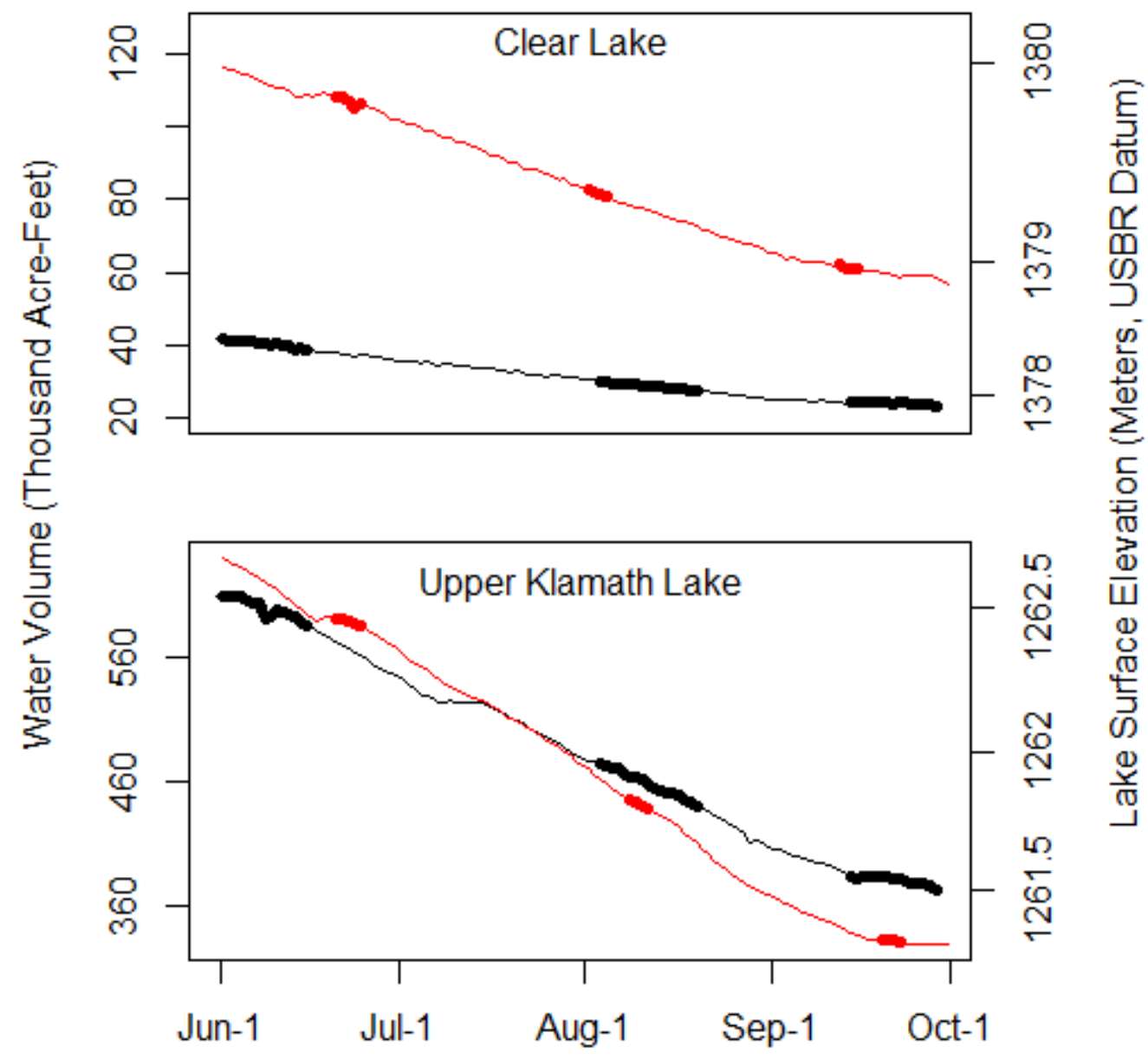

Figure 3. Capacity and surface elevations in Clear Lake, California, and Upper Klamath Lake, Oregon, in 2015 (black) and 2016 (red). Sampling periods are highlighted in bold for each lake and year and given in tables 1 and 2 for 2016 and in Burdick and others (2016) for 2015.

\section{Quality of Age Estimates}

Two-reader agreement on the number of annuli on fin rays decreased with an increase in the number of annuli on the fin rays (fig. 4). Of the suckers estimated to be age- 0 , two readers agreed on the ages of 99 percent during initial examination. Of the suckers estimated to be age-1 or age-2, readers agreed on the age during initial examination 86 percent of the time. Of suckers estimated to be from age- 3 to age-14, readers agreed on the age during initial examination only 65 percent of the time (fig. 4). Readers counted within one annuli of each other during initial blind reads where there were 3 annuli or less. The discrepancy in reads and therefore the certainty of correct age estimates decreased above three annuli (fig. 4). There appeared to be a consistent upward bias for reader two relative to reader one. This consistent difference is most likely due to either misidentification of the first or last annuli. However, it is also possible that there was a difference in which marks readers were calling annuli. 


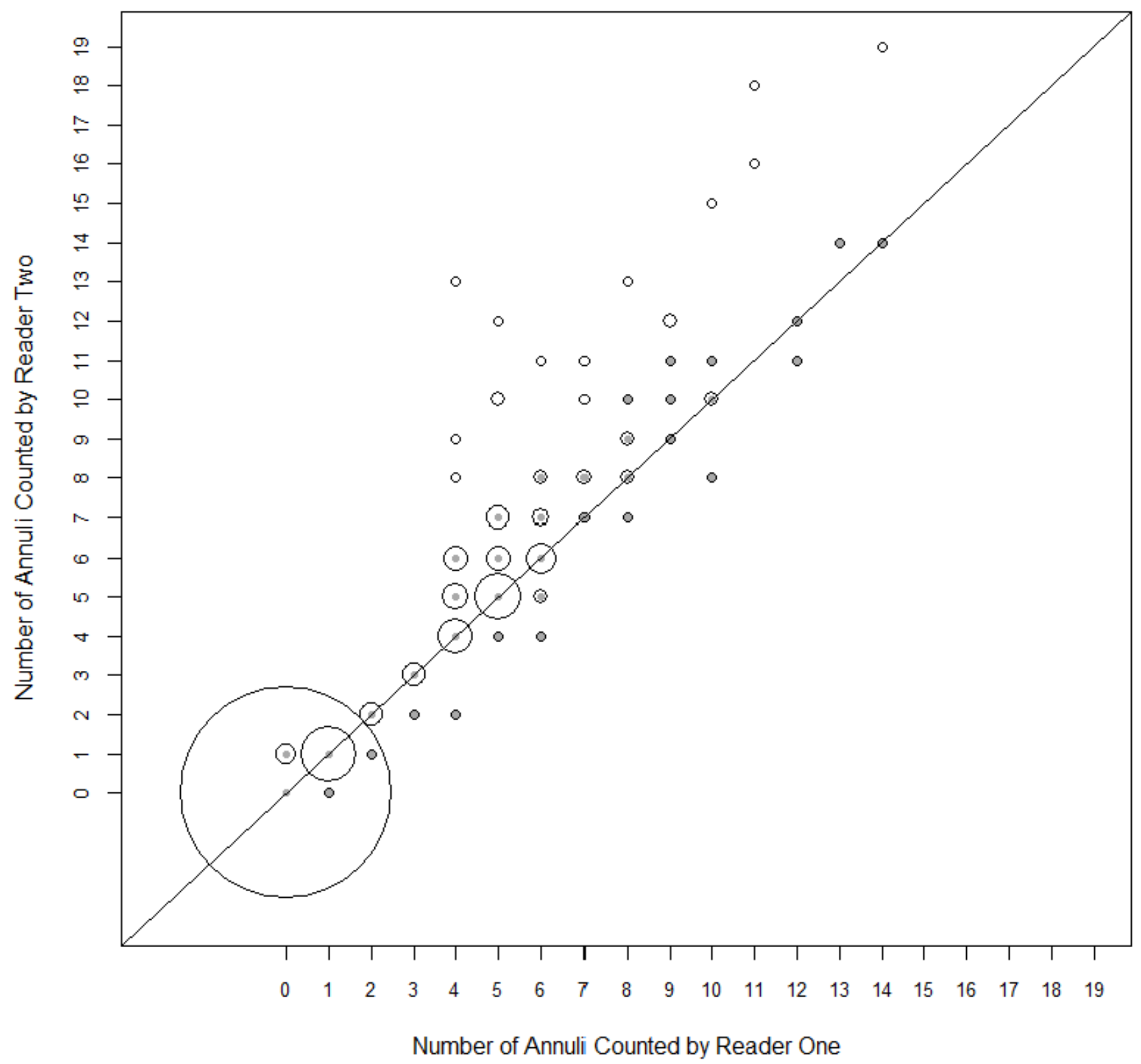

Figure 4. Comparison of fin ray annuli counts by two readers for each fin ray for suckers captured in Upper Klamath Lake, Oregon, and Clear Lake, California, 2016. The radius of each circle indicates the number of fish with the same coordinates on this plot. Bubble size is scaled relative to the largest bubble, which represents 429 fish that were determined to have no annuli by both readers. Gray dots in the middle of circles indicate fin rays for which two independent reads differed by no more than two, and that were used in analyses. A line showing perfect agreement between readers is given for reference. 
Comparison of lengths between suckers from Upper Klamath Lake that were aged using fin rays and small suckers (SL $\leq 89 \mathrm{~mm}$ ) with no fin rays collected, validated our length-based age assumptions. In August 2016, SL of suckers for which no fin rays were collected ranged from 19 to 63 $\mathrm{mm}$, and suckers having no annuli on fin rays (age-0) ranged from 45 to $115 \mathrm{~mm}$. In September, SL of suckers for which no fin rays were collected ranged from 58 to $89 \mathrm{~mm}$ and SL of age-0 suckers ranged from 79 to $103 \mathrm{~mm}$. For comparison, suckers having one annulus on fin rays (age-1) had SLs ranging from 97 to $162 \mathrm{~mm}$ in June and August. No age-1 suckers were captured in Upper Klamath Lake in September for length comparison.

We estimated age based on length for two suckers from Clear Lake from which no fin rays were collected. We presumed that a $67 \mathrm{~mm}$ SL sucker captured on August 4 was age 0, because its length was within the range of lengths of suckers having no annuli in August (59 to $93 \mathrm{~mm}$ SL), and smaller than the six suckers having one annulus captured during August and September (100-109 mm SL). We presumed that a $97 \mathrm{~mm}$ SL sucker captured on September 12 was age-0, because its length was within the range of lengths for other age-0 suckers captured in September (85-129 mm SL) and it was smaller than suckers with a single annulus. A third sucker from Clear Lake from which no fin ray was taken was captured September 14 measured $102 \mathrm{~mm} \mathrm{SL}$, which was within the range of lengths for both age- 0 and age- 1 suckers in Clear Lake at the same time of year. Therefore, we were unable to assign an age to this fish and we excluded it from further analyses.

\section{Sucker Taxa Composition, Age, and Length in Fixed and Randomly Determined Sites}

Taxa composition, age, and SL of age- 0 suckers were similar between fixed and randomly determined sample sites in Upper Klamath Lake but not in Clear Lake (figs. 5-7). Total CPUE for all age classes combined and for age-0 suckers captured in August and September specifically was similar between fixed and randomly determined site locations in both Upper Klamath Lake and Clear Lake (table 4). Most differences in the composition of our catches in Clear Lake between fixed and randomly determined site locations could be attributed to randomly determined sites in the eastern lobe of Clear Lake (figs. 5-7). Catches at randomly determined sites in the eastern lobe of Clear Lake had a greater proportion of Lost River suckers and shorter age-0 shortnose suckers than fixed sites in the eastern lobe or any sites in the western lobe (figs. 5-7). Due to spatial differences in catch composition in Clear Lake, we summarize catches by eastern and western lobes throughout this report. 
Fixed
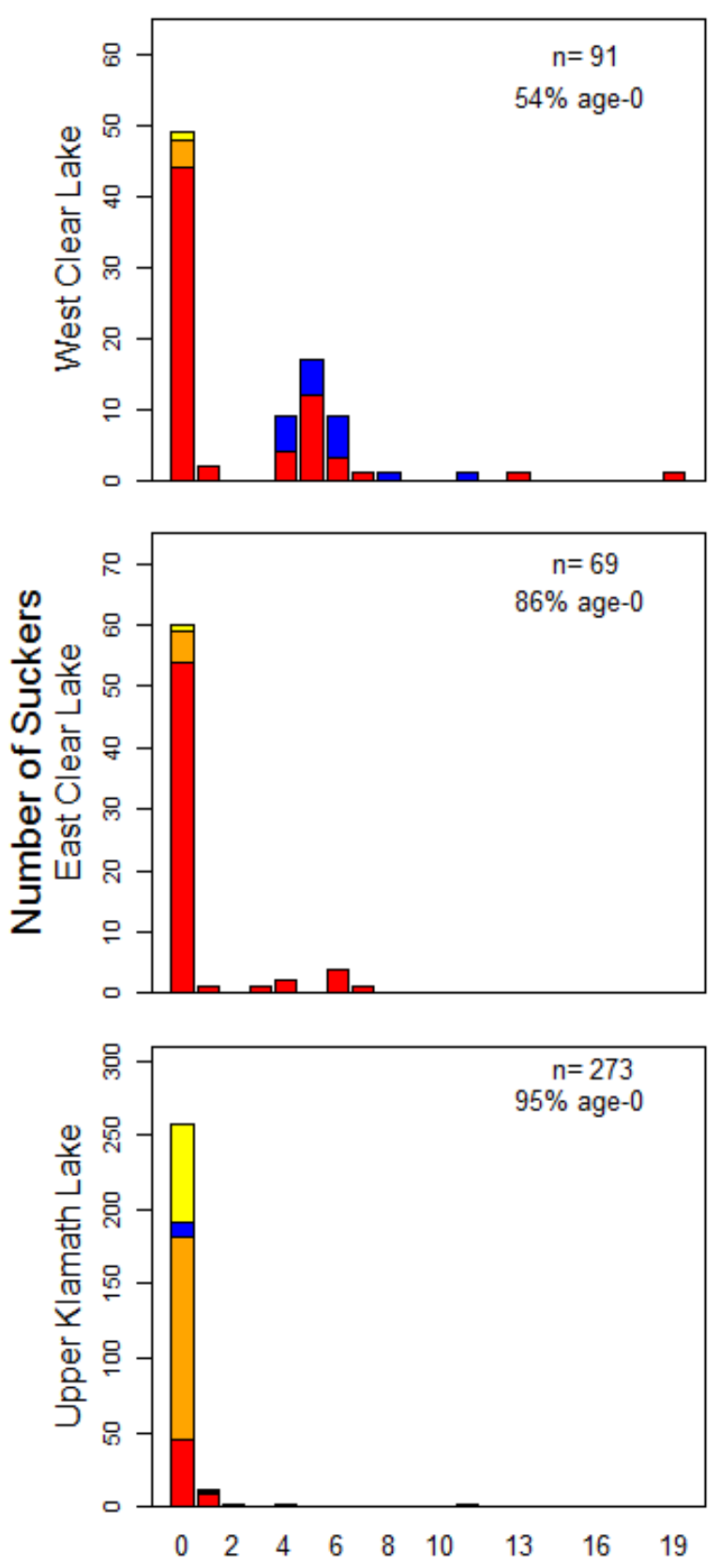

Random
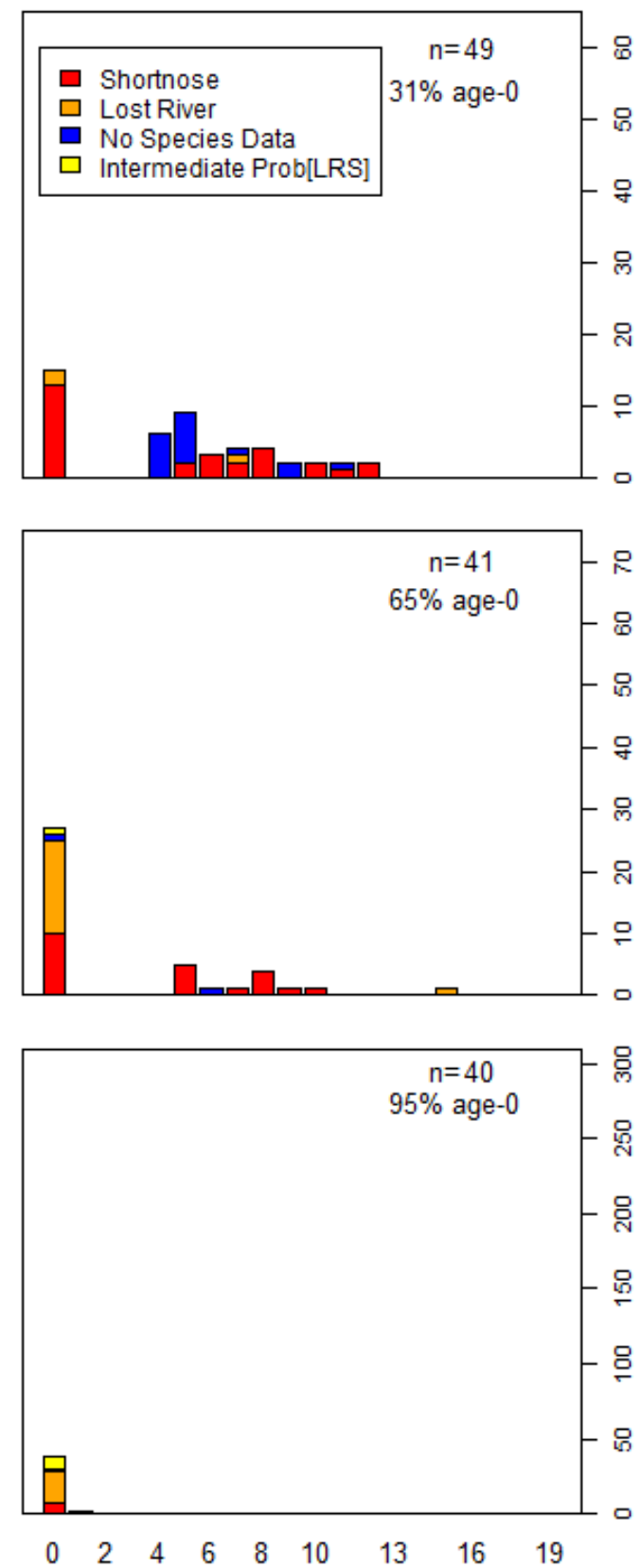

Number of Annuli

Figure 5. Number of annuli on suckers collected at fixed and randomly determined sample sites in western and eastern lobes of Clear Lake, California, and in Upper Klamath Lake, Oregon, 2016. Taxa were identified as the probability of STRUCTURE assignment as LRS (Prob[LRS]). Fish with Prob[LRS] $\leq 0.05$ are called shortnose suckers, fish with Prob[LRS] $\geq 0.95$ are called Lost River suckers, and fish with $0.05<\operatorname{Prob}[\mathrm{LRS}]<0.95$ are called Intermediate Prob [LRS]. The numbers of fish used to create each panel are given $(\mathrm{n})$. The percentage of suckers in each plot that had no annuli on fin rays (age-0) are given in each plot. 
Fixed
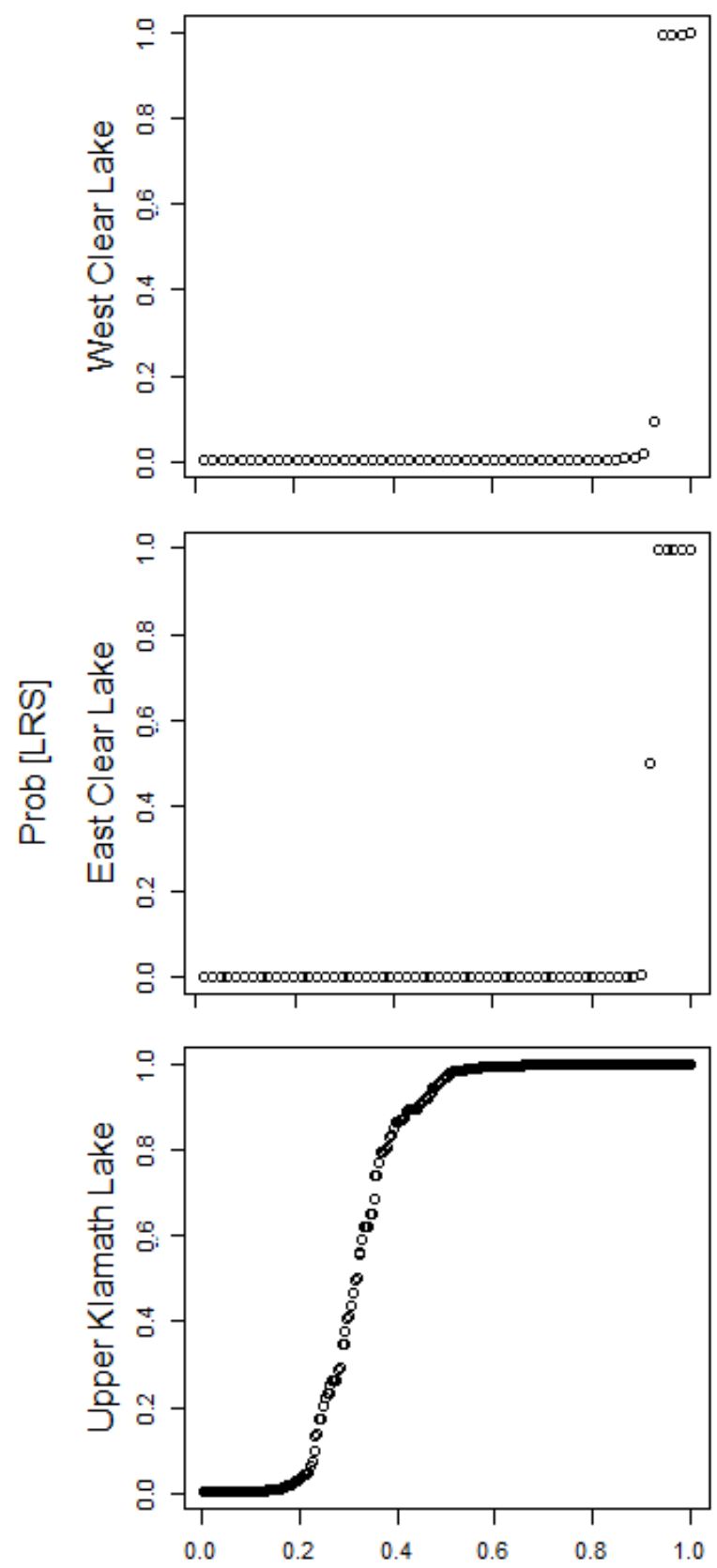

Random
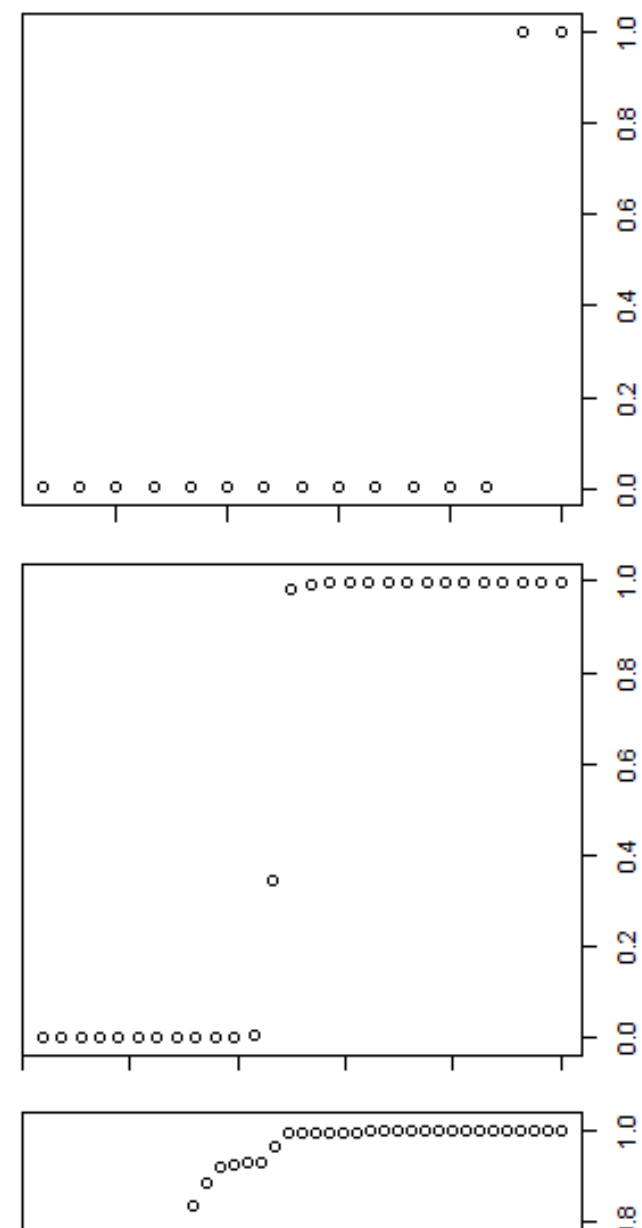

$\stackrel{\infty}{\circ}$

$\stackrel{\infty}{\circ}$

$\stackrel{+}{\circ}$

ำ

$\stackrel{0}{\circ}$

Cumulative Proportion

Figure 6. Probability of taxa assignment based on STRUCTURE (Prob [LRS]) at fixed and randomly determined sites in the eastern and western lobes of Clear Lake Reservoir, California, and Upper Klamath Lake, Oregon, 2016. Site locations are shown in figures 1 and 2. 
Fixed
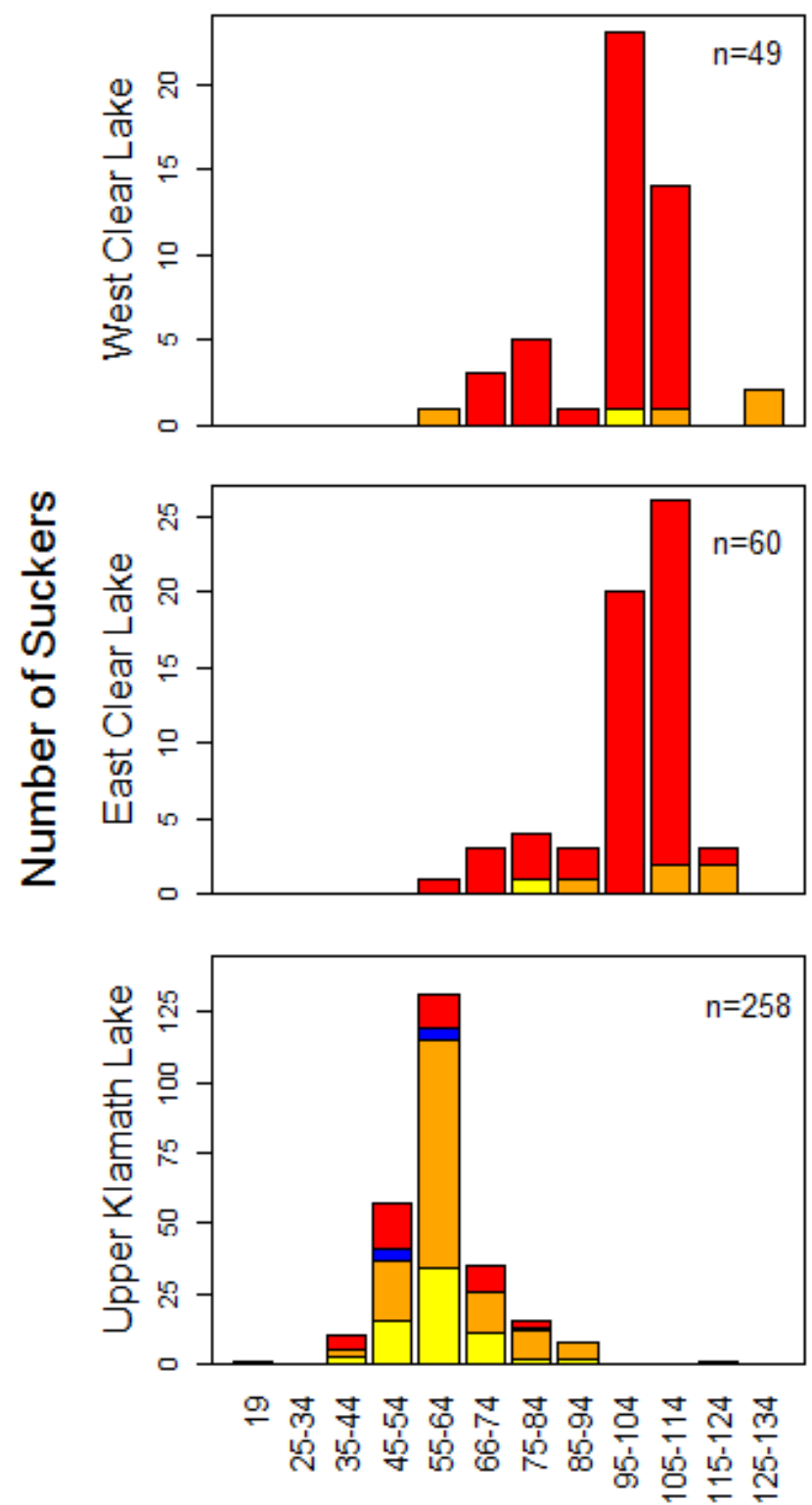

Random
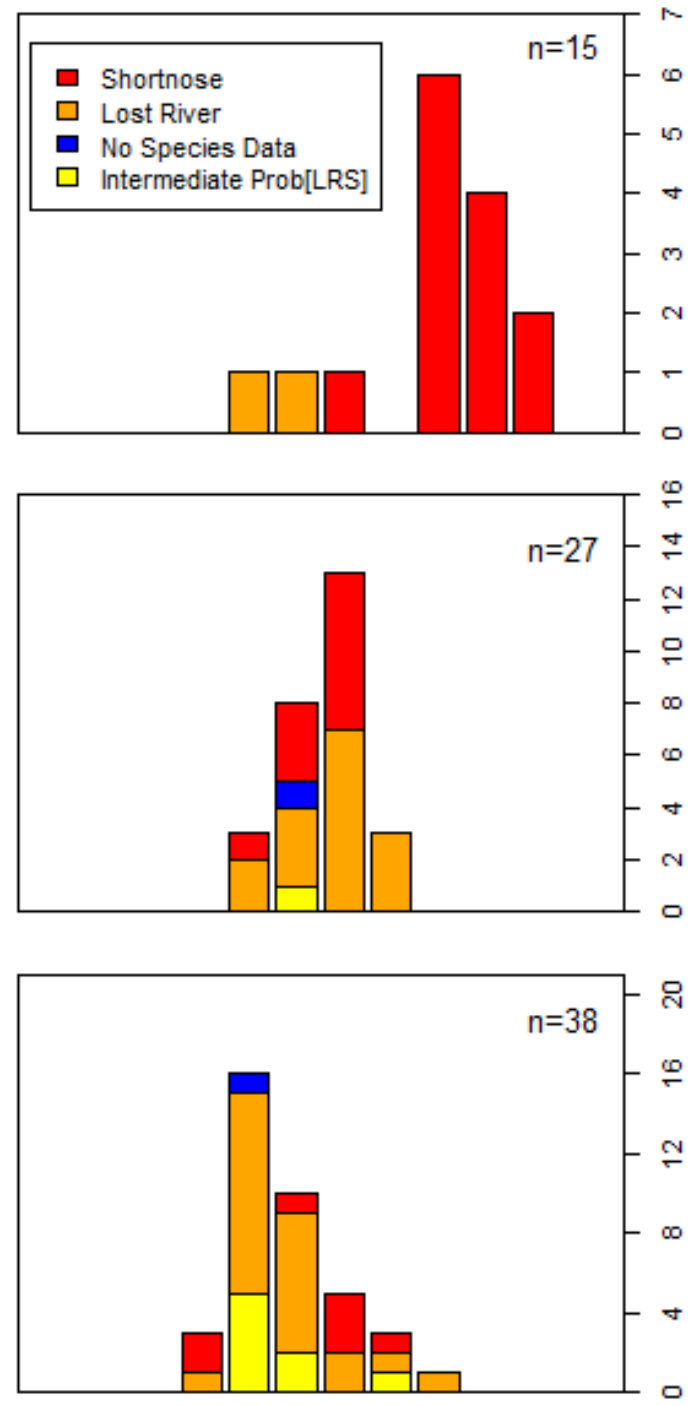

の

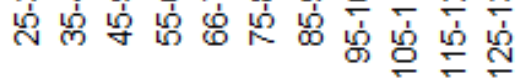

\section{Standard Length $(\mathrm{mm})$}

Figure 7. Standard lengths of age-0 suckers collected at fixed and randomly determined locations in western and eastern lobes of Clear Lake, California, and in Upper Klamath Lake, Oregon, 2016. Taxa were identified as the probability of STRUCTURE assignment as LRS (Prob[LRS]). Fish with Prob[LRS] $\leq 0.05$ are called shortnose suckers, fish with Prob[LRS] $\geq 0.95$ are called Lost River Suckers and fish with $0.05<$ Prob[LRS] $<0.95$ are called Intermediate Prob [LRS]. The numbers of fish used to create each panel are given (n). 
Table 4. Catch statistics for fixed and randomly determined sample sites in Clear Lake Reservoir, California, and Upper Klamath Lake, Oregon, 2016.

[The percentage of nets to successfully capture one or more sucker at fixed and randomly determined sites in Upper Klamath Lake and in the eastern and western lobes of Clear Lake, mean and standard deviation (SD) catch per net (CPUE) in nets that successfully captured one or more sucker, and total suckers captured in all nets set (Total CPUE) are given for each seasonal sampling period. All ages of fish are combined in this table]

\begin{tabular}{lcc|cc|cc}
\hline & \multicolumn{2}{c|}{ Western Clear Lake } & \multicolumn{2}{c|}{ Eastern Clear Lake } & \multicolumn{2}{c}{ Upper Klamath Lake } \\
\cline { 2 - 7 } & Fixed & Random & Fixed & Random & Fixed & Random \\
\hline Percentage & 28 & 28 & 62 & 62 & 36 & 30 \\
Mean (SD) & $1.75(1.11)$ & $2.58(2.50)$ & $5.31(6.36)$ & $5.40(4.28)$ & $4.03(6.17)$ & $2.00(1.62)$ \\
Total CPUE & 0.48 & 0.73 & 3.29 & 5.13 & 1.01 & 0.85 \\
\hline
\end{tabular}

\section{Sucker Taxa and Age Composition}

All age-0 suckers in both lakes were captured in August or September. Ninety-five percent of all suckers captured in Upper Klamath Lake were age-0 (table 5). Just over half (51 percent) of the 313 suckers captured in Upper Klamath Lake were Lost River suckers, 21 percent had intermediate Prob[LRS], 25 percent were shortnose suckers, and 3 percent were not identified to taxa (fig. 6). Only 17 suckers older than age- 0 were captured in Upper Klamath Lake (fig. 5). One of these was an age-1 Lost River sucker, one was a $452 \mathrm{~mm}$ SL age-11 sucker that was not identified to taxa, and two were age-1 suckers with intermediate Prob[LRS]. One was an age-4 sucker identified using morphology as a Klamath largescale sucker. There were also 11 age-1, one age- 2 and one age- 3 shortnose suckers collected from Upper Klamath Lake.

A smaller majority (60 percent) of suckers were age-0 in Clear Lake compared to Upper Klamath Lake (table 5). Of the 151 age-0 suckers captured in Clear Lake, 80 percent were shortnose suckers, 2 percent had intermediate Prob [LRS], 17 percent were Lost River suckers, and 1 percent were not identified to taxa. All Lost River suckers captured in Clear Lake were age-0 except for two adults that were age 7 and 11 with SLs of 525 and $545 \mathrm{~mm}$ respectively. Suckers captured in Clear Lake were estimated to be up to 19 years old, and 15 cohorts were detected (fig. 5). Three age-1 shortnose suckers were captured in Clear Lake in 2016. These three fish ranged from 100 to $109 \mathrm{~mm}$ SL and were captured in September. No age-2 suckers and only one age-3, $245 \mathrm{~mm}$ SL, shortnose sucker was identified from Clear Lake; age classes that would have hatched in 2014 and 2013, respectively. Excluding the 2016 cohort, age classes with the most individuals captured were from 4 to 6 years old and were estimated to have hatched between 2010 and 2012. 
Table 5. Catch per net and percent of age-0 suckers for each taxa captured in Clear Lake Reservoir, California and Upper Klamath Lake, Oregon in 2016.

[The number of total and age-0 suckers captured in each taxa, the catch per net (CPUE), and percentage of each taxa that were age- 0 are given. Taxa were identified based on either genetic or morphological information as described in the methods]

\begin{tabular}{lcccc|cccc}
\hline & \multicolumn{5}{c|}{ Clear Lake } & \multicolumn{4}{c}{ Upper Klamath Lake } \\
\cline { 2 - 9 } \multicolumn{1}{c}{ Taxa } & $\begin{array}{r}\text { Number } \\
\text { suckers }\end{array}$ & $\begin{array}{c}\text { Number } \\
\text { age-0 }\end{array}$ & $\begin{array}{c}\text { Age-0 } \\
\text { CPUE }\end{array}$ & $\begin{array}{c}\text { age-0 } \\
\text { (percent) }\end{array}$ & $\begin{array}{c}\text { Number } \\
\text { suckers }\end{array}$ & $\begin{array}{c}\text { Number } \\
\text { age-0 }\end{array}$ & $\begin{array}{c}\text { Age-0 } \\
\text { CPUE }\end{array}$ & $\begin{array}{c}\text { age-0 } \\
\text { (percent) }\end{array}$ \\
\hline Lost River Suckers & 28 & 26 & 0.09 & 93 & 159 & 158 & 0.46 & 99 \\
Shortnose Suckers & 182 & 121 & 0.42 & 66 & 65 & 52 & 0.15 & 80 \\
Intermediate Prob [LRS] & 3 & 3 & 0.01 & 100 & 77 & 75 & 0.03 & 97 \\
No Taxa Data & 37 & 1 & 0.00 & 3 & 12 & 11 & 0.22 & 92 \\
All Taxa Suckers & 250 & 151 & 0.52 & 60 & 313 & 296 & 0.87 & 95 \\
\hline
\end{tabular}

\section{Juvenile Sucker Year Class Strength}

Age-0 Lost River suckers appeared to be more numerous in 2016 than 2015 in Upper Klamath Lake, but age- 0 shortnose suckers appeared to be equally abundant between years (tables 6 and 7). Indices of abundance for suckers with intermediate Prob[LRS] did not indicate if abundance was greater in one of the years (tables 6 and 7). Catches in additional trap net sampling that occurred in July of 2016 also indicated a relatively high abundance in 2016. A total of 73 percent of July nets captured age- 0 suckers, the mean \pm SD CPUE for nets that captured age- 0 suckers was $6.8 \pm 5.9$, and the total CPUE (all age-0 suckers/number of nets) was 5 age-0 suckers per net. 
Table 6. Catch statistics for the 2015 cohorts of suckers from Upper Klamath Lake, Oregon.

[The percentage of nets to successfully capture one or more sucker in each taxa, mean and standard deviation (SD) catch per net (CPUE) in nets that successfully captured one or more sucker, and total suckers captured in all nets set (Total CPUE) are given for each seasonal sampling period. Because statistics are shown by year-class, fish captured in 2016 are age-1 in this table. Data for 2015 are reported in Burdick and others (2016)]

\begin{tabular}{|c|c|c|c|c|c|c|}
\hline & & $\begin{array}{c}\text { August 3-21 } \\
2015\end{array}$ & $\begin{array}{c}\text { September } 15-29 \\
2015 \\
\end{array}$ & $\begin{array}{c}\text { June } 20-24 \\
2016 \\
\end{array}$ & $\begin{array}{c}\text { August 8-12 } \\
2016 \\
\end{array}$ & $\begin{array}{c}\text { September } 19-23 \\
2016 \\
\end{array}$ \\
\hline Number of Nets & & 118 & 70 & 116 & 116 & 107 \\
\hline \multirow[t]{3}{*}{ Lost River Suckers } & Percentage & 37 & 4 & $<1$ & 0 & 0 \\
\hline & Mean (SD) & $1.63(0.79)$ & $1.00(0.00)$ & $1.00(0.00)$ & $0.00(0.00)$ & $0.00(0.00)$ \\
\hline & Total CPUE & 0.37 & 0.04 & 0.01 & 0.00 & 0.00 \\
\hline \multicolumn{7}{|l|}{ Intermediate } \\
\hline \multirow[t]{3}{*}{ Prob[LRS] } & Percentage & 18 & 7 & 2 & 0 & 0 \\
\hline & Mean (SD) & $1.67(1.39)$ & $1.20(0.44)$ & $1.00(0.00)$ & $0.00(0.00)$ & $0.00(0.00)$ \\
\hline & Total CPUE & 0.30 & 0.09 & 0.02 & 0.00 & 0.00 \\
\hline \multirow[t]{3}{*}{ Shortnose Suckers } & Percentage & 18 & 20 & 7 & $<1$ & 0 \\
\hline & Mean (SD) & $2.57(2.20)$ & $1.14(0.36)$ & $1.13(0.35)$ & $1.00(0)$ & $0.00(0.00)$ \\
\hline & Total CPUE & 0.46 & 0.23 & 0.08 & $<0.01$ & 0.00 \\
\hline \multirow[t]{3}{*}{ Total Suckers } & Percentage & 41 & 25 & 9 & $<1$ & 0.0 \\
\hline & Mean (SD) & $2.81(3.34)$ & $1.53(0.91)$ & $1.09(0.30)$ & $1.00(0)$ & $0.00(0.00)$ \\
\hline & Total CPUE & 1.14 & 0.38 & 0.10 & $<0.01$ & 0.00 \\
\hline
\end{tabular}


Table 7. Catch statistics for 2016 cohorts of suckers from Upper Klamath Lake, Oregon.

[The percentage of nets to successfully capture one or more sucker in each taxa, mean and standard deviation (SD) catch per net (CPUE) in nets that successfully captured one or more age-0 sucker and total suckers captured in all nets set (Total CPUE) are given for each seasonal sampling period]

\begin{tabular}{llrr}
\hline & & $\begin{array}{c}\text { August 8-12, } \\
\text { 2016 }\end{array}$ & $\begin{array}{r}\text { September } \\
\text { 19-23, 2016 }\end{array}$ \\
\hline Number of Nets & & 116 & 107 \\
Lost River Suckers & Percentage & 34 & 16 \\
& Mean (SD) & $3.5(4.4)$ & $1.18(0.39)$ \\
& Total CPUE & 1.18 & 0.19 \\
& & & \\
Intermediate Prob[LRS] & Percentage & 28 & 7 \\
& Mean (SD) & $2.1(1.8)$ & $1.28(0.48)$ \\
& Total CPUE & 0.56 & 0.08 \\
Shortnose Suckers & & & \\
& Percentage & 18 & 10 \\
& Mean (SD) & $1.8(1.5)$ & $1.27(0.34)$ \\
& Total CPUE & 0.32 & 0.13 \\
Total Suckers & & & \\
& Percentage & 48 & 24 \\
& Mean (SD) & $4.5(6.5)$ & $1.69(1.09)$ \\
& Total CPUE & 2.17 & 0.41 \\
\hline
\end{tabular}

Age-0 suckers of all three taxa were captured in Clear Lake in 2016, but no age-0 suckers from any taxa were captured in Clear Lake in 2015. Indices of age-0 Lost River sucker abundance were much greater in Upper Klamath Lake than in the western lobe of Clear Lake but similar to the eastern lobe of Clear Lake in 2016 (tables 7 and 8). The number of successful age- 0 nets were too few in Clear Lake to make taxa specific comparisons between lakes. 
Table 8. Catch statistics for the 2016 cohorts of suckers from eastern and western lobes of Clear Lake Reservoir, California.

[Percentage of nets to successfully capture one or more sucker in each taxa, mean and standard deviation (SD) catch per net (CPUE) in nets that successfully captured one or more age-0 sucker, and total suckers captured in all nets set (Total CPUE) are given for each seasonal sampling period]

\begin{tabular}{|c|c|c|c|c|c|}
\hline & & \multicolumn{2}{|c|}{ Western Lobe } & \multicolumn{2}{|c|}{ Eastern Lobe } \\
\hline & & August 1-5- & September 12-16 & August 1-2 & September 14-15 \\
\hline Number of nets & & 70 & 86 & 30 & 7 \\
\hline \multirow[t]{4}{*}{ Lost River suckers } & Percentage & 3 & 5 & 36 & 14 \\
\hline & $\begin{array}{l}\text { Mean } \\
\text { (SD) }\end{array}$ & $1(0)$ & $1(0)$ & $3.2(3.3)$ & $4(0)$ \\
\hline & Total & & & & \\
\hline & CPUE & 0.03 & 0.05 & 1.14 & 0.57 \\
\hline \multirow[t]{4}{*}{ Intermediate Prob[LRS] } & Percentage & $0 \%$ & $1 \%$ & $14 \%$ & $0 \%$ \\
\hline & Mean & & & & \\
\hline & $\begin{array}{l}\text { (SD) } \\
\text { Total }\end{array}$ & NA & $1(0)$ & $1.0(0)$ & NA \\
\hline & CPUE & 0.00 & 0.01 & 0.14 & 0.00 \\
\hline \multirow[t]{4}{*}{ Shortnose suckers } & Percentage & 8 & 47 & 50 & 57 \\
\hline & $\begin{array}{l}\text { Mean } \\
\text { (SD) }\end{array}$ & $1.3(0.5)$ & $1.65(0.92)$ & $2.4(1.3)$ & $15.5(7.6)$ \\
\hline & Total & & & & \\
\hline & CPUE & 0.10 & 0.77 & 1.21 & 8.86 \\
\hline \multirow[t]{4}{*}{ All suckers } & Percentage & 16 & 50 & 64 & 86 \\
\hline & $\begin{array}{l}\text { Mean } \\
\text { (SD) }\end{array}$ & $1.2(0.4)$ & $1.7(0.9)$ & $4.0(3.5)$ & $17.0(21.7)$ \\
\hline & Total & & & & \\
\hline & CPUE & 0.20 & 0.84 & 0.29 & 14.57 \\
\hline
\end{tabular}

\section{Apparent Relative Juvenile Sucker Survival}

The indices of apparent age-0 sucker August-September survival in Upper Klamath Lake were lowest for Lost River suckers, intermediate for suckers with intermediate Prob[LRS], and greatest for shortnose suckers in 2015 and 2016 (table 9). Indices of August-September age-0 survival (total

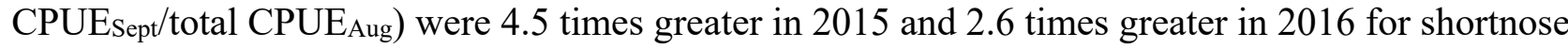
suckers than Lost River suckers. The index of age-0 sucker August-September survival was similar between years for each of the three taxa (table 9). The index of overwinter survival was 0.35 for Upper Klamath Lake shortnose suckers and was not calculated for other taxa due to very low CPUE of age-0 suckers in September and age-1 suckers in June (table 6). 
Table 9. Indices of August-September survival for age-0 suckers captured in Upper Klamath Lake, Oregon, 2015 and 2016.

\begin{tabular}{lll}
\hline \multicolumn{1}{c}{ Identification of suckers } & $\mathbf{2 0 1 5}$ & $\mathbf{2 0 1 6}$ \\
\hline Lost River Suckers & 0.11 & 0.16 \\
Intermediate Prob[LRS] & 0.30 & 0.14 \\
Shortnose Suckers & 0.50 & 0.41 \\
Total suckers & 0.33 & 0.19 \\
\hline
\end{tabular}

Age-0 shortnose sucker CPUE in Clear Lake increased between August and September of 2016, while CPUE declined for Lost River suckers during the same time period. CPUE for age- 0 shortnose suckers increased by approximately 7 times in both the eastern and western lobes of Clear Lake between August and September (table 8). Age-0 Lost River suckers CPUE was similar between August and September in the western lobe and decreased by about 50 percent in the eastern lobe.

\section{Length and Apparent Growth of Age-0 Suckers}

Age-0 suckers were larger in August 2016 in Clear Lake than in Upper Klamath Lake. A categorical definition of sucker taxa increased model parsimony in the 2016 2-lake data subset over a continuous sucker taxa definition by 10.8 AICc units (model fit statistics not shown) and was used in subsequent modeling. Lake had a stronger effect on August age-0 sucker SL than taxa. A model that used only lake to describe variation in SL carried 80 percent of the relative model weights (table 10). Whereas, a model that included both lake and a categorically defined taxa as additive parameters carried 15 percent of the model weights. Age-0 suckers in the 2016 2-lake data subset were on average $( \pm \mathrm{SE}) 14.9( \pm 1.1) \mathrm{mm}$ SL longer in Clear Lake $(75.2 \pm 7.8 \mathrm{~mm} \mathrm{SL})$ than in Upper Klamath Lake (60.3 $\pm 6.4 \mathrm{~mm} \mathrm{SL})$ in August 2016 (fig. 8).

Table 10. Model selection table for models describing variation in standard length of age- 0 suckers captured in Upper Klamath or Clear Lakes in August 2016.

[Taxonomic classification was modeled as a categorical variable (Lost River suckers, shortnose suckers, or suckers with intermediate Prob[LRS]). The following values are given in this table, the number of model parameters, AICc adjusted for sample size (AICc), difference in AIC relative to the most parsimonious model ( $\triangle \mathrm{AICc}$ ) and probability that the model is the best within the list for describing the dataset (weight)]

\begin{tabular}{lcrrr}
\hline \multicolumn{1}{c}{ Model } & Parameters & AlCc & AAICc & Weight \\
\hline Lake & 2 & $1,530.7$ & 0.00 & 0.80 \\
Taxa + Lake & 5 & $1,534.1$ & 3.32 & 0.15 \\
Lake*Taxa + Taxa + Lake & 6 & $1,536.5$ & 5.80 & 0.04 \\
Taxa & 3 & $1,644.8$ & 114.08 & 0.00 \\
\hline
\end{tabular}




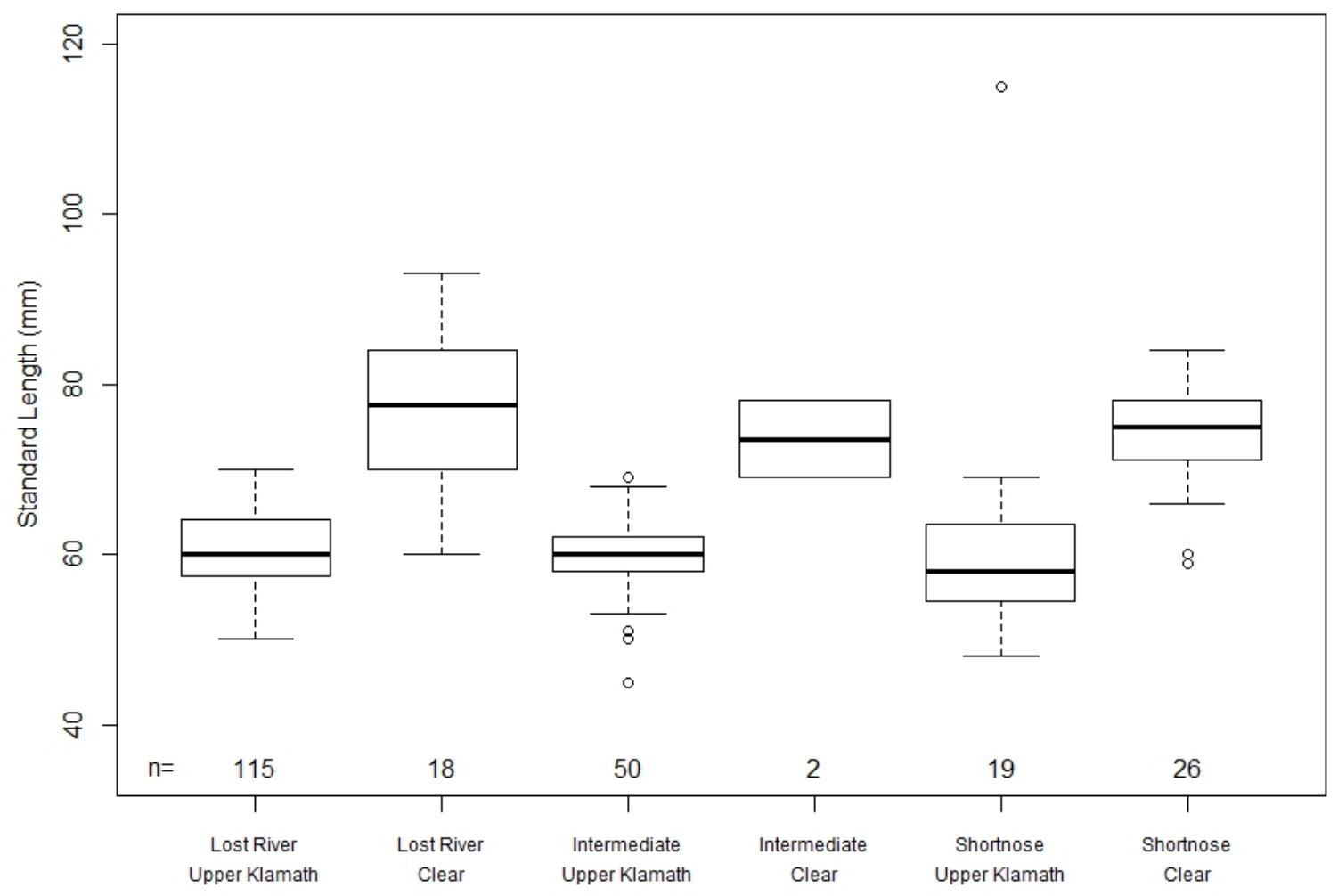

Figure 8. Boxplot of standard lengths for age-0 suckers captured in August 2016 captured in Upper Klamath Lake, Oregon, and Clear Lake, California. Taxa definitions are based on the probability of correct taxa assignment produced by program STRUCTURE, as described in section, "Methods." Fish with uncertain taxa assignment are called "Intermediate" in this plot.

August SL of age- 0 suckers in 2015 and 2016 in Upper Klamath Lake varied relative to both year and taxa. When the continuous and categorical parameterization of taxa were compared as methods to describe SL in this 2-year data subset of data from Upper Klamath Lake, the continuous parametrization had a probability of 0.99 of being the more parsimonious option (model fit statistics not shown), and was therefore used in the following models. The interactive model (Taxa*Year) best described the variation in the August age-0 sucker SL (table 11). August age-0 sucker SL increased with an increase in the probability of being a Lost River sucker in 2015, but these two variables were not related in 2016 (fig. 9). Age-0 shortnose suckers were on average \pm SD slightly smaller than age-0 Lost River suckers in 2015, but both taxa were about the same size in 2016 (table 12; fig. 9). 
Table 11. Model selection table for models describing variation in standard length of age- 0 suckers captured in Upper Klamath Lake in August 2015 and 2016.

[Taxonomic classification was modeled as a continuous variable based on the probability of taxa assignment as determined in STRUCTURE analysis. The following values are given in this table, the number of model parameters, AIC adjusted for sample size (AICc), difference in AIC relative to the most parsimonious model ( $\triangle \mathrm{AICc}$ ), and probability that the model is the best within the list for describing the dataset (weight)]

\begin{tabular}{|c|c|c|c|c|}
\hline Model & Parameters & AICc & $\triangle \mathrm{AICC}$ & Weight \\
\hline Taxa*Year & 4 & 1650.1 & 0.00 & 1.00 \\
\hline Taxa & 2 & 1684.7 & 34.59 & 0.00 \\
\hline Year + Taxa & 3 & 1685.0 & 34.86 & 0.00 \\
\hline Year & 2 & 1708.4 & 58.25 & 0.00 \\
\hline
\end{tabular}

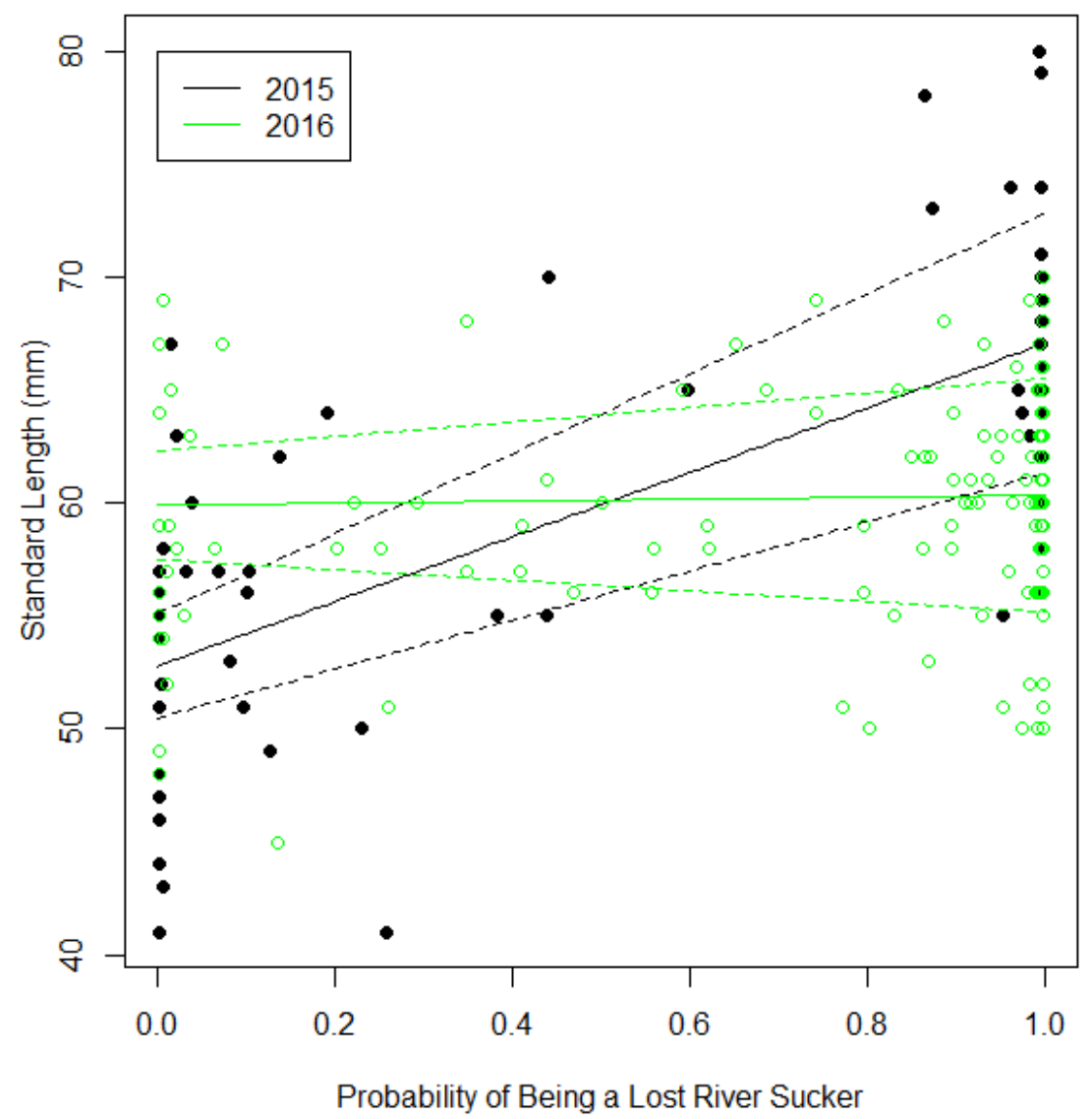

Figure 9. Probability of taxa assignment as a Lost River sucker (Prob [LRS]) versus standard length for age-0 suckers captured in Upper Klamath Lake, Oregon, August 2015 and 2016. 
Table 12. Mean (standard deviation) standard length of age- 0 shortnose (a combination of shortnose and Klamath largescale suckers) and Lost River suckers captured in Upper Klamath Lake, Oregon, August 2015 and 2016.

\begin{tabular}{crl}
\hline \multicolumn{1}{c}{ Taxa } & $\mathbf{2 0 1 5}$ & \multicolumn{1}{c}{$\mathbf{2 0 1 6}$} \\
\hline Shortnose suckers & $52(6.4)$ & $61(14.3)$ \\
Lost River suckers & $66(5.9)$ & $60(4.7)$ \\
\hline
\end{tabular}

When compared to long-term data collected in Upper Klamath Lake, the SL of shortnose suckers from August 8-11 was similar in 2016 to 2001-04 and 2006-07 (Burdick and others, 2017). Shortnose suckers were longer in August 2016 than on the same dates in August 2005 (42 $\pm 8.1 \mathrm{~mm}$ SL). Mean SL of August caught Lost River suckers from Upper Klamath Lake was similar between 2016 and 2004, and 2006 and 2007. Lost River suckers captured in August 2016 were about $6 \mathrm{~mm}$ longer than the same taxa caught on the same dates in 2001-03 and 2005.

Age-0 shortnose suckers collected from Clear Lake in 2016 appeared to grow more between August and September than age-0 shortnose suckers collected from Upper Klamath Lake in 2015. The Lake*Month model carried all of the AICc weights when compared to the Lake+Month model. Age-0 shortnose suckers were on average ( \pm SE) $19.3 \pm 2.2 \mathrm{~mm}$ longer in September than in August in Upper Klamath Lake in 2015, and 30.41 $\pm 1.3 \mathrm{~mm}$ longer in September than in August in Clear Lake in 2016.

\section{Afflictions}

Lernaea sp. were one of the more prevalent abnormalities noted for suckers in both. Lernaea sp. were three times less prevalent in 2015 and two times less prevalent in 2016 on age- 0 shortnose suckers than age-0 Lost Rivers suckers from Upper Klamath Lake (table 13). There was a smaller proportion of age-1 and older suckers with attached Learnea sp in 2016 in Clear Lake than in 2015 in Clear Lake or in either year in Upper Klamath Lake (table 14). The intensity of infection of Lernaea sp. was generally low for suckers from both lakes in 2015 and 2016. Up to two Lernaea sp. were attached per age-1 or older sucker in Clear Lake. Except for one adult sucker that had 25 Lernaea sp., all suckers from Upper Klamath Lake had six or fewer attached Lernaea sp.

Table 13. Proportions of age-0 suckers with attached Lernaea sp., Upper Klamath Lake, Oregon, 2016.

[Note that there were no age- 0 suckers captured in Clear Lake in 2015]

\begin{tabular}{|c|c|c|c|}
\hline Taxonomic group & $\begin{array}{c}\text { Upper Klamath } \\
\text { Lake } \\
2015\end{array}$ & $\begin{array}{c}\text { Upper Klamath } \\
\text { Lake } \\
2016\end{array}$ & $\begin{array}{c}\text { Clear Lake } \\
2016\end{array}$ \\
\hline Lost River sucker & 0.31 & 0.24 & 0.04 \\
\hline Intermediate Prob[LRS] & 0.37 & 0.20 & 0.00 \\
\hline Shortnose sucker & 0.10 & 0.12 & 0.03 \\
\hline Total & 0.23 & 0.21 & 0.03 \\
\hline
\end{tabular}

Table 14. Proportions of age-1 and older suckers with attached Lernaea sp., Upper Klamath Lake, Oregon, 2016.

[Sample size given in parentheses]

\begin{tabular}{lcc}
\hline \multicolumn{1}{c}{ Lake } & $\mathbf{2 0 1 5}$ & $\mathbf{2 0 1 6}$ \\
\hline Upper Klamath Lake & $0.11(18)$ & $0.24(17)$ \\
Clear Lake & $0.29(24)$ & $0.05(99)$ \\
\hline
\end{tabular}


Petechial hemorrhages of the skin on age-0 suckers were more prevalent in Upper Klamath Lake than in Clear Lake in 2016 and within Upper Klamath Lake in 2015 than 2016 (table 15). Within Upper Klamath Lake, these small skin hemorrhages were twice as prevalent on age-0 Lost River suckers than age- 0 shortnose suckers in 2015, but the prevalence was similar between taxa in 2016. In 2015, the prevalence of petechial hemorrhages of the skin decreased on age-0 suckers in Upper Klamath Lake from 39 to 7 percent between August and September sampling periods. In 2016, all observations of these skin hemorrhages on all ages of suckers in Upper Klamath Lake occurred in August. Skin hemorrhages occurred at low rates on age-1 and age-2 suckers in Upper Klamath Lake in 2015 (4 percent) and 2016 (11 percent).

Table 15. Proportions of age- 0 suckers in each of three taxa that had petechial hemorrhages of the skin, Upper Klamath Lake, Oregon, and Clear Lake Reservoir, California.

[No age-0 suckers were captured in Clear Lake in 2015]

\begin{tabular}{lccc}
\hline & $\begin{array}{c}\text { Upper Klamath } \\
\text { Lake }\end{array}$ & $\begin{array}{c}\text { Upper Klamath } \\
\text { Lake }\end{array}$ & $\begin{array}{c}\text { Clear Lake } \\
\text { 2016 }\end{array}$ \\
\hline Taxonomic group & $\mathbf{2 0 1 5}$ & $\mathbf{2 0 1 6}$ & 0.00 \\
Lost River sucker & 0.50 & 0.20 & 0.00 \\
Intermediate Prob[LRS] & 0.32 & 0.15 & 0.01 \\
Shortnose sucker & 0.24 & 0.13 & 0.01 \\
Total & 0.34 & 0.17 & \\
\hline
\end{tabular}

Deformed opercula, black-spot forming parasites, and infections presumed to be Columnaris were observed on small proportions of suckers from Upper Klamath Lake in 2016 but not on suckers from Clear Lake in either 2015 or 2016 . Deformities of the opercula were noted on similar small proportions of age-0 suckers in Upper Klamath Lake in 2015 and 2016 (table 16). Deformed opercula were more common on shortnose suckers than Lost River suckers in 2015, but the opposite was true in 2016 (table 16). Deformed opercula were not noted on age-1 and older suckers. When deformities occurred, they exposed nearly all of the gill filaments on one or both sides of the fish. Black-spot forming parasites, presumed to be the encysted metacercariae of trematodes, were visible on the skin of 5 percent of age- 0 suckers from Upper Klamath Lake in 2015 and 2 percent of age-0 suckers from Upper Klamath Lake in 2016. These black spots did not occur on age-1 or older suckers in either lake. Patches of dead tissue with a yellowish outer edge appearing on the dorsal or caudal areas, presumed to be Columnaris infections, appeared on 5 age-0 suckers from Upper Klamath Lake captured on August 10, 2016. Fish with presumed Columnaris made up small proportions of age-0 Lost River suckers (4.4 percent), age-0 suckers with intermediate Prob [LRS] (4.4 percent), and age-0 shortnose suckers (3.2 percent).

Table 16. Proportions of age-0 suckers with deformed opercula, Upper Klamath Lake, Oregon, 2015 and 2016.

\begin{tabular}{lcc}
\hline \multicolumn{1}{c}{ Taxanomic group } & $\mathbf{2 0 1 5}$ & $\mathbf{2 0 1 6}$ \\
\hline Lost River sucker & 0.04 & 0.12 \\
Intermediate Prob[LRS] & 0.07 & 0.11 \\
Shortnose sucker & 0.08 & 0.02 \\
Total & 0.06 & 0.10 \\
\hline
\end{tabular}


Other abnormalities noted on small numbers of fish included damaged fins (three suckers from each lake), blindness (two suckers from Upper Klamath Lake), and lamprey wounds. Lamprey wounds were noted on eight suckers from Clear Lake and four suckers from Upper Klamath Lake. All suckers with lamprey wounds that were collected in 2016 were dead when nets were retrieved from the water. Lamprey were often captured with suckers but were not always attached to suckers when captured.

\section{Discussion}

Different early life history dynamics appear to control the entry of adult suckers into spawning populations in Upper Klamath and Clear Lakes. Year classes for both taxa are formed every year in Upper Klamath Lake (Burdick and Martin, 2017), but year class formation may not occur every year in Clear Lake. However, juvenile suckers appear to survive to adulthood in Clear Lake (Burdick and others, 2016). In Upper Klamath Lake, there is a substantial decline in apparent abundance of juvenile suckers by September of the first year that continues through age-1, ending in the near absence of age2 and older juvenile suckers (Burdick and others, 2016; Burdick and Martin, 2017). The negative consequences of these dynamics may be worse for Lost River suckers, because they appear to be in low abundance in Clear Lake and disappear faster from Upper Klamath Lake relative to shortnose suckers.

\section{Upper Klamath Lake Year Class Strength}

The Upper Klamath Lake 2016 year class of all sucker taxa combined appeared to be relatively abundant compared to year classes formed since 2007, with the possible exception of 2011. Our indices of year-class strength were greater in 2016 than 2015 when gear and methods used were similar. In Upper Klamath Lake, indices of August relative abundance were greater for age-0 Lost River suckers in 2016 than in 2015. Indices of August relative abundance of age-0 shortnose suckers were similar between years. Therefore, the differences in relative abundance indices for age- 0 where all taxa are combined are specifically a result of differences in the apparent relative abundance of Lost River suckers. The 2016 year-class also appeared to be stronger than year classes from 2007 to 2010 and 2012-14, which were sampled using similar gear fished at different times and locations than in the present study (Burdick and Martin, 2017). However, differences in sample locations and seasonal timing between our present study and data reported by Burdick and Martin (2017) make it inappropriate to quantitatively compare apparent abundance of year classes between 2016 and years prior to 2015. Age-0 suckers also were sampled in Upper Klamath Lake by USGS from 2001 to 2006 using trap nets with different dimensions than in the present study and were not sampled in 2011 (Burdick and Martin, 2017). Simon and others (2013) consistently sampled for juvenile suckers from 1996 to 2012 using a combination of beach seines, cast nets, and otter trawls. Both groups identified 2006 as a year with moderate (Simon and others, 2013) to high (USGS) relative abundance within their data sets. Simon and others (2013) also identified 2011 as a year with a relatively high abundance of age-0 suckers. However, given the difference in gear types, sample locations, and sampling methods between studies, these data sets are not directly comparable with 2015 and 2016 data.

The percentage of August-caught age- 0 suckers that were Lost River suckers was much lower than expected in 2015 and 2016, based on the prevalence of Lost River sucker adult spawners. Approximately 10 times as many adult Lost River suckers as shortnose suckers make spawning migrations up the Williamson and Sprague Rivers every year (Hewitt and others, 2015). Furthermore, a second spawning population of Lost River Suckers occurs on the eastern shoreline of Upper Klamath Lake (Hewitt and others, 2015). Lost River suckers also are about three times more fecund than shortnose suckers (Scoppettone and Vinyard, 1991). Therefore, the vast majority of August-caught age-0 suckers should be Lost River suckers if spawning success, egg survival, larval survival, early ( $\leq$ $45 \mathrm{~mm}$ SL) juvenile survival, and gear susceptibility were similar between the two taxa. Lost River suckers comprised only 33 percent in 2015 and 79 percent in 2016 of the age- 0 suckers captured in 
August (tables 6 and 7). By September, the percentages of age- 0 suckers that were Lost River were only 11 percent in 2015 and 48 percent in 2016 (tables 6 and 7). Burdick and Martin (2017) noted that the percentage of age- 0 suckers that were Lost River suckers ranged from 40 to 85 percent in mid-July from 2001 to 2014, except in 2007 when Lost River suckers made up 95 percent of the age- 0 catch in mid-July.

\section{Upper Klamath Lake Indices of Age-0 Sucker Survival}

Age-0 sucker CPUE declined more between August and September for Lost River suckers than for shortnose suckers in both 2015 and 2016. Furthermore, only one age-1 Lost River suckers was captured compared to 13 age-1 shortnose suckers in 2016. Burdick and Martin (2017) noted a seasonal decline in the ratio of Lost River to shortnose suckers from mid-July to early September in 2003, 2007, 2009 , and 2015. However, because they had incomplete taxa identification data they were unable to tell if this pattern was due to shortnose recruiting to sampling gear throughout the summer sampling period, a decline in Lost River sucker apparent abundance, or both. Data presented in this report indicates a more rapid decrease in the apparent abundance of Lost River suckers than for shortnose suckers. The greater decline in Lost River sucker CPUE could be due to (1) emigration of Lost River suckers out of Upper Klamath Lake, (2) a greater tendency for Lost River suckers than shortnose suckers to avoid our sampling gear as they age and grow, (3) lower survival of Lost River suckers than shortnose suckers, or (4) some combination of these factors.

\section{Clear Lake Sucker Year Class Strength and Formation}

Catch-at-age data presented in this report, and corroborated by previous annual data on age- 0 sucker catch in Clear Lake, indicate year-class strength was lowest in 2013-15, intermediate in 2012 and greatest in 2011 and 2016. Age-0 suckers were captured but not identified to taxa in 2011, 2012, and 2013, but were not captured in 2014 and 2015 in Clear Lake despite extensive sampling with trap nets (Burdick and Rasmussen, 2012 and 2013; Burdick and others, 2016).

We captured one age- 3 shortnose sucker, representing the 2013 age class, from Clear Lake in 2016. While between reader agreement on ages decreased around age-3, both readers counted 3 annuli during blind reads of the fin ray for this particular fish. The length of this sucker also was within the range of age- 3 suckers captured in 2015, further supporting a correct age identification. Furthermore, three shortnose suckers from the 2013 year class were captured at age- 2 in 2015 (Burdick and others, 2016), which suggests the formation of a 2013 age class, albeit possibly small. A 2014 year class of shortnose suckers has yet to be detected (Burdick and others, 2016). Three shortnose suckers with a single annuli each are possible members of the 2015 year class. However, disagreement in age for one of these fish and their small size (100-109 mm SL) given their September capture dates make it possible that these fish were actually age-0 suckers. Given the uncertainty about the ages of the suspected 2015 year-class members and that no age-0 suckers were captured in 2015 (Burdick and others, 2016), we are not confident that a 2015 year class was formed. A 2012 year class has been detected annually, but in smaller numbers within each year than the 2011 year class (Burdick and Rasmussen, 2013). In 2012 and 2013, suckers were not identified to taxa, but members of the 2012 year class were genotyped and (or) identified morphologically as shortnose starting in 2014 . The indices of abundance for age-0 suckers not identified to taxa in 2011 and shortnose suckers in 2016 were similar. A total of 21 suckers presumed to be age- 0 based on length $(<100 \mathrm{~mm}$ SL) were captured in 50 nets set in Clear Lake in from July to September in 2011 for a total CPUE of 0.42 fish per net (Burdick and Rasmussen, 2012). A total of 121 age-0 shortnose suckers was captured in 182 nets set in August and September of 2016 for a total CPUE of 0.42 fish per net. These annual total CPUE values for the 2 best years on record in Clear Lake are below average compared to annual summer-time CPUE in Upper Klamath Lake from 2007 to 2015 (around 0.62 sucker per net; Burdick and Martin, 2017). 
Low relative abundance of juvenile Lost River suckers compared to juvenile shortnose suckers in Clear Lake was expected (figs. 5-7), because 73 percent or more of adult suckers captured in fall trammel-net sampling in Clear Lake are shortnose suckers (Hewitt and Hayes, 2013). Only 29 Lost River suckers have been captured in trap nets during juvenile summer sampling since 2014, when we started using genetics to identify suckers to taxa. Of these, 26 were age-0, two were adults (ages 7 and 11) captured in 2016, and one was an age-3 Lost River sucker captured in 2014 representing the 2011 year class (Burdick and others, 2015). No juvenile Lost River suckers were captured in Clear Lake in 2015. Due to very low catches of juvenile Lost River sucker in Clear Lake the life history dynamics of this taxa in this lake are still poorly understood.

Year-class strength in Clear Lake appears to be limited by both spring inflows and lake surface elevation. In years that produced moderate or abundant year classes (2011, 2012, and 2016), lakesurface elevation exceeded 1,378.9 m (4,524 ft) during the entire February to May spawning season (fig. 10). Spawning season lake surface elevation also peaked at no less than $1,379.54 \mathrm{~m}(4,526 \mathrm{ft})$ in each of these 3 years. A smaller year class was produced in 2012 when Clear Lake surface elevations increased by only $0.78 \mathrm{~m}$ from January to April indicating lower Willow Creek inflows, than in 2011 and 2016 when lake elevation increased by 2.72 and $2.37 \mathrm{~m}$, respectively. In 2013, the lake surface elevation increased from January to April, reached 1,378.9 (4,524 ft) on February 16, and peaked at 1,379.2 $\mathrm{m}(4,524.8 \mathrm{ft})$ in April. Flat or declining lake surface elevations indicated that there were no substantial Willow Creek inflows after about April 3, 2013. This may have resulted in a very narrow time period in 2013 when both lake elevations and Willow Creek inflows were sufficient to allow adult suckers to spawn. Juvenile sucker production could not be confirmed for year classes from 2014 and 2015 when maximum lake surface elevations were 1,378.0 m (4,521 ft) in 2014 and 1,378.2 m (4,522 $\mathrm{ft})$ in 2015. Adult PIT tagged suckers detected on remote detection stations in Willow Creek were lower in 2014 (6 fish) and 2015 (35 fish) than other years on record when 121 (in 2007) to 2,946 (in 2011) PIT tagged suckers were detected (D. Hewitt, U.S. Geological Survey, oral commun., 2017). An increase in age- 0 shortnose sucker CPUE in Clear Lake between August and September 2016 could be due to the concentrating effect of declining lake elevations, new age- 0 fish entering the lake between these sampling periods, or both. Rather than a decrease in CPUE from August to September, CPUE of age-0 shortnose suckers increased while the lake volume decreased by about 36 percent (fig. 3). However, age-0 Lost River sucker CPUE was similar from August to September. This may be an indication of declining age-0 Lost River sucker abundance, given the declining lake volume. 


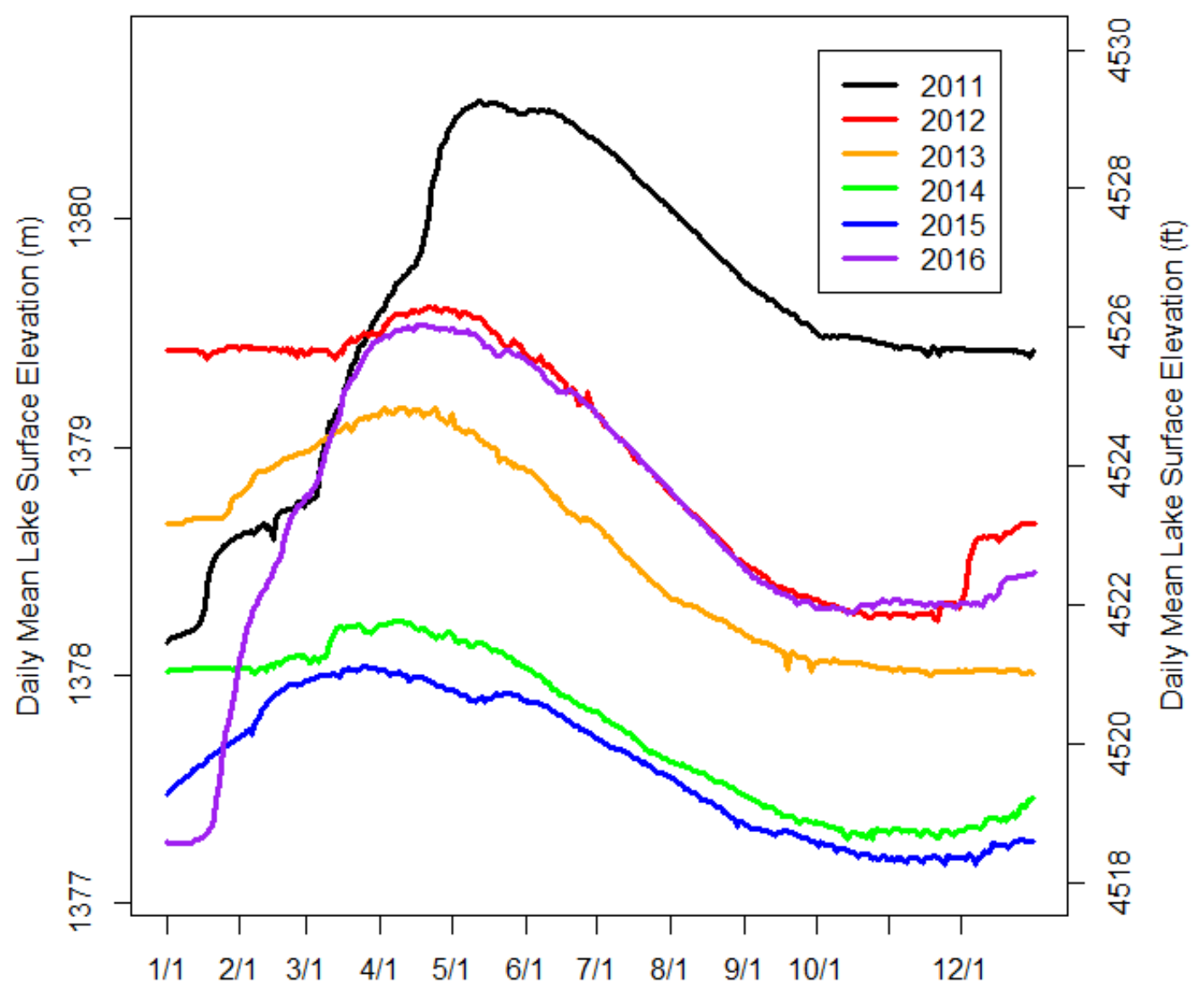

Figure 10. Lake surface elevations, Clear Lake Reservoir, California, 2011-15. Data from Bureau of Reclamation, accessed on August 23, 2017. 


\section{Age-0 Sucker Length and Apparent Growth}

Differences in the timing of the adult spawning runs in Upper Klamath Lake in 2015 and 2016 may help explain differences in August sizes of age-0 suckers. Lost River suckers were longer than shortnose suckers in August 2015, but the two taxa were about the same size in August 2016. There was more separation in spawning run timing between adult Lost River and shortnose suckers in 2015 than in 2016. Most Lost River suckers migrated up the Williamson River in late March and early April, and most shortnose suckers migrated in late April 2015. In contrast, a rapid increase in water temperatures from about 10 to about $15^{\circ} \mathrm{C}$ was associated with a peak in the spawning migration of both Lost River and shortnose suckers in early April 2016 (D. Hewitt, U.S. Geological Survey, oral commun., 2017).

Longer age-0 suckers in Clear Lake than Upper Klamath Lake in August 2016 could be due to differences in the timing of spawning and egg hatching. Adult shortnose and Lost River suckers from Clear Lake start to make spawning migrations when Willow Creek water temperatures reach or exceed $6{ }^{\circ} \mathrm{C}$. Clear Lake sucker spawning migrations generally occur in March, but the timing may vary depending on water temperatures and sufficient flows to permit access to Willow Creek (Hewitt and Hayes, 2013). Most of the spawning migration for both taxa in Willow Creek occurred in February of 2016 with a smaller pulse of suckers migrating upstream in March (D. Hewitt, U.S. Geological Survey, oral commun., 2017). In Upper Klamath Lake, spawning migrations begin when the Williamson River water temperatures reach or exceed $10{ }^{\circ} \mathrm{C}$ for Lost River suckers and $12{ }^{\circ} \mathrm{C}$ for shortnose suckers (Hewitt and others, 2015). In Upper Klamath Lake, Lost River sucker spawning migrations generally occur in late March to early April and shortnose suckers migrate from as early as mid-March to early May.

The difference in August length of age- 0 suckers between lakes also may be affected by faster larval and early juvenile (SL $\leq 45 \mathrm{~mm}$ and prior to August) growth rates in Clear Lake than Upper Klamath Lake. Age-0 suckers captured August 8 to 11, 2016 in Clear Lake were approximately $15 \mathrm{~mm}$ longer than age- 0 suckers and approximately $45 \mathrm{~mm}$ shorter than age- 1 suckers of any taxa captured in Upper Klamath Lake on the same dates in any year from 2001 to 2015 (Burdick and Martin, 2017). Greater mid-summer juvenile shortnose sucker August-September growth in Clear Lake in 2016 than in Upper Klamath Lake in 2015 appears to corroborate the hypothesis of faster growth in Clear Lake. However, it is important to keep in mind that this comparison of growth between lakes may be confounded with annual differences.

Faster young of year growth of suckers in Clear Lake than Upper Klamath Lake may be related to a number of potential stressors in Upper Klamath Lake, not including water temperature or prey availability. Prey abundance and water temperature within certain ranges can be positively correlated and fish density can be negatively correlated with juvenile Catastomid growth (Chen and Harvey, 1995; Robinson and Childs, 2001). Mean densities of Oligochaetes and Chironomids, two primary prey items for suckers, are greater than 6,000 and 4,000 individuals per $\mathrm{m}_{-}^{2}$ respectively in Upper Klamath Lake (Stauffer-Olsen and others, 2017), indicating prey is unlikely to be a growth limiting factor for suckers in Upper Klamath Lake. Furthermore, Clear Lake benthic invertebrate densities have not been reported, but field observations made during this study indicate benthic invertebrate densities appear to be relatively low. Although the diel variation in water temperature is greater in Clear Lake than Upper Klamath Lake, mean daily summer time water temperatures are similar between lakes (Burdick, Elliott and others, 2015). Therefore, water temperature is not an obvious growth limiting factor for suckers in Upper Klamath Lake or growth promoting factor for suckers in Clear Lake. 
Because mean June-September catch rates for all fish taxa combined are about eight times greater in Upper Klamath Lake than in Clear Lake, it is plausible that fish density had a negative effect on growth of Lost River and shortnose suckers (Burdick, Elliott, and others, 2015). Additionally, stress from any number of sources can reduce growth in fishes (Barton, 2002). Other potential fish stressors in Upper Klamath Lake include both low and highly variable dissolved oxygen concentrations, both high and variable $\mathrm{pH}$, occasionally high un-ionized ammonia concentrations, algal toxins, disease, and parasites (Burdick, Elliott, and others, 2015).

\section{Afflictions}

Lernaea sp. parasitism was one of the most common afflictions noted on suckers captured in either lake. The prevalence of Lernaea sp. that we observed in 2016 in both lakes was similar to that reported for Upper Klamath Lake from 2007 to 2015 (5-21 percent; Burdick and others, 2008; Burdick and Brown, 2010; Bottcher and Burdick, 2010; Burdick and VanderKooi, 2010; Burdick and Hewitt, 2012). Lernaea sp. are an ectoparasitic copepod that can cause severe inflammation at the attachment site and may possibly provide a pathway for bacterial infection (Berry and others, 1991). However, Burdick, Elliott, and others (2015) observed that inflammation associated with Lernaea sp. attached to suckers was not associated with systemic infections. Even when the prevalence of this parasite is high, the intensity was low which may lower the risk of associated infections. Therefore, while Lernaea $\mathrm{sp}$. were prevalent they probably pose little to no threat to the survival of suckers in either lake.

Petechial hemorrhages of the skin can be caused by any number of irritants, including bacteria, toxins, or abrasion (Ferguson and others, 2011). These small hemorrhages were present in no more than 1 percent of suckers captured in Clear Lake from 2014 to 2016. Petechial hemorrhages of the skin have been common in Upper Klamath Lake since monitoring for them began in 2014 (Burdick, Elliott, and others, 2015). The very low prevalence of observed hemorrhages in Clear Lake relative to Upper Klamath Lake indicates that abrasions due to our method of capture were unlikely to be the primary cause of the hemorrhages. Burdick and others (2017) examined the hemorrhages microscopically and did not observe associated bacteria or other parasites. The higher prevalence of petechial hemorrhages of the skin in August than in September within Upper Klamath Lake indicates the cause may be associated with August conditions. The reduction in prevalence from August to September could indicate that either suckers recover from the condition or die at a higher rate if they have it.

Deformed opercula are observed on a small percentage of suckers from Upper Klamath Lake, but have yet to be observed in Clear Lake (Burdick, Elliott and others, 2015). The prevalence of deformed opercula in 2015 and 2016 Upper Klamath Lake monitoring was similar to the prevalence of this deformity in suckers collected only at Fish Banks in 2013 and 2014 (8 percent; Burdick, Elliott, and others, 2015). Although deformed or shortened opercula are considered non-lethal for hatcheryreared fish, they may be associated with increased mortality in wild fish (Beraldo and others, 2003; Barkstedt and others, 2015). The presence of this deformity in Upper Klamath Lake where first year mortality is high, and absence in Clear Lake where first year mortality is low, is consistent with deformity associated mortality. Barkstedt and others (2015) found that that the prevalence of opercular deformities on three taxa of wild-caught catostomids decreased with age. Based on a presumption that deformed opercula are a permanent condition for catostomids, they hypothesized opercula deformities were associated with mortality. Opercular deformities may lower resistance to oxygen stress and predispose fish to infections by bacteria, parasites, and fungi (Galeotti and others, 2000; Beraldo and others, 2003), or reduce predator avoidance. These deformities have numerous potential causes including low pH, inbreeding, hybridization (Winemiller and Taylor, 1982; Tringali and others, 2001), 
nutritional deficiency (Chávez de Martínez, 1990; Lall, 2002), heavy metals, pesticides, and high egg incubation temperatures (Boglione and others, 2013). Nutrition related to skeletal deformities in fish includes too much or too little dietary bioavailable phosphorus $(\mathrm{P})$ relative to calcium uptake and deficiencies in vitamins $\mathrm{C}$ and $\mathrm{D}$, phospholipids, unsaturated fatty acids, or magnesium (Lall, 2002; Cahu and others, 2003).

The black spots observed on the skin of suckers from Upper Klamath Lake were most likely melanin-encysted metacercaria of the trematode Bolbophorus damnificus (Kent and others, 2014). These same trematodes were observed on fathead minnows collected from Upper Klamath Lake (Kent and others, 2017), but were not identified on suckers in surveys in Clear Lake from 2014 to 2016 (Burdick, Elliott, and others, 2015). When present, trematode metacercaria are associated with focal, mild to severe inflammation (Burdick, Elliott, and others, 2015). Because the inflammation is focal it is unlikely that the metacercaria cause direct mortality, except perhaps if they are in very high abundance on a particular fish. Trematodes have a complex life cycle that includes sequentially infecting a mollusk, fish, and bird hosts (Kent and others, 2017). They can cause their intermediate hosts to suffer from increased predation by reducing fish performance or changing fish behavior (Barber and others, 2000). Kent and others (2017) used genetic techniques to identify trematode cercariae carried by 11 species of snails in Upper Klamath Lake, but were unable to identify a species of snail that carried Bolbophorus damnificus. The apparent absence of Bolbophorus damnificus infected fish in Clear Lake may be due to the absence of a mollusk host for the parasite. Furthermore, it is possible that the high abundance of fathead minnows carrying Bolbophorus damnificus in Upper Klamath Lake lead to increased infection rates in suckers (Kelly and others, 2009; Kent and others, 2017).

All other abnormalities were present on small proportions of suckers. Due to the small numbers of fish with the less common abnormalities, we are unable to assess relative importance of these conditions to sucker survival. Presumed Columnaris sp. was reported on small percentages of age-0 suckers for the first time in 2016. This reflects a change in awareness and protocol rather than an increased presence of the infection, as this was the first year we asked all field staff to look for signs of this disease. Lamprey were fatal to a small proportion of suckers that we captured. Because lamprey occasionally were still attached to suckers and often still in the net when the net was pulled, it is possible that capture in the net made suckers more susceptible to lamprey. Therefore, we do not presume that lamprey are a major source of juvenile sucker mortality.

\section{Sources of Potential Sampling Bias}

The timing of sampling, relative to when age- 0 suckers grow large enough to be captured in our gear and begin to disappear from catches, has the potential to bias indices of apparent relative abundance and survival. For example, peak catch rates occur around the first few weeks of August in Upper Klamath Lake in most years (for example, 2001-07; Burdick and Martin, 2017). In other years, catch rates in Upper Klamath Lake increase throughout August (for example, 2009 and 2010; Burdick and Martin, 2017) or already appear to be declining in at the beginning of August when sampling began (for example, 2003). A temporal pattern to age- 0 catch rates in Clear Lake has not be determined. If sampling occurs before or after the peak in age-0 sucker abundance in a given year the indices of apparent relative abundance would be lower than if sampling occurred during peak abundance. Although July 2016 sampling was not designed to be representative, relatively high catch rates would point out how earlier sampling might have indicated a greater abundance of suckers in 2016 and higher indices of apparent mortality. 
Aging error increased at ages 4 and older, which may have introduced bias in our resulting conclusions about the strength of year classes hatched prior to 2013 in Clear Lake. Reader disagreement not only increased, but there appeared to be a consistent bias between readers. Because we were only able to compare aging estimates between readers, we cannot tell if the bias was toward older or younger ages. We believe potential bias introduced by aging error in the uncensored fish was minimal, because the relative strength of the 2011 and 2012 year classes as estimated in 2016 was consistent with the relative strength of these year classes as reported in the years that each were hatched.

It is possible that our sample design under-represented offshore age-0 Lost River sucker populations in Upper Klamath Lake, which may have been longer in SL than age-0 suckers captured near shore during the same sampling events. Although sample sizes in 2015 were too small to test for differences in lengths, mean SLs controlled for taxa were nearly identical between random and fixed sites (Burdick and others, 2016). The length difference in 2016 may be due to larger age-0 Lost River suckers being captured further from shore, but we captured too few age-0 Lost River suckers offshore to specifically test this hypothesis. While 50 percent of randomly determined sites were located offshore, only 16 fixed sites (14-15 percent) were located offshore. We minimized potential bias by using data from both fixed and randomly determined sites. Nevertheless, we recommend continued random sampling and potentially more offshore sampling in future years to ensure samples accurately represent populations.

Trap nets are likely size selective for fish of an intermediate size range, which may have led to underrepresentation of both age-0 suckers and suckers larger than about 230-300 mm SL. Fish small enough to pass through the mess of our nets, such as small age- 0 suckers ( $<45 \mathrm{~mm} \mathrm{SL}$ ), have a low catchability in trap nets (Burdick and Martin, 2017). Because adult suckers (>300 mm SL) are captured at high rates in spring and fall trammel net sampling and infrequently in summer time trap net sampling we presume that trap nets select for smaller suckers than trammel nets (Hewitt and Hayes, 2013). Burdick and others (2016) did not find length a length based pattern in the proportions of PIT tagged and released suckers (70-229 $\mathrm{mm} \mathrm{SL)} \mathrm{that} \mathrm{were} \mathrm{recaptured,} \mathrm{indicating} \mathrm{there} \mathrm{was} \mathrm{not} \mathrm{strong} \mathrm{size}$ selectivity within this size range.

Sample heterogeneity in Clear Lake was primarily attributable to randomly determined sample sites in the southeastern lobe that had a larger proportion of age- 0 Lost River suckers and shorter age- 0 shortnose suckers than other parts of the lake. This southeastern part of Clear Lake is shallower than the rest of the lake and in some years dries out completely. In 2016, the lake surface elevation was high enough that Willow Creek emptied directly into the eastern lobe, rather than following an artificial stream channel leading toward the dam. The proximity of the eastern lobe sample sites in 2016 to the spawning area may explain the presence of smaller age-0 suckers. Another possibility is that the shallowness of the eastern lobe compared to the western lobe in 2016 may have been attractive to this age class. The probability of capturing age- 0 suckers decreases somewhat as water depth increases from around one to four meters (Burdick and Hewitt, 2012). By incorporating samples from randomly selected sites in the eastern lobe of Clear Lake into our analysis we minimized potential sample bias. The sample composition in the eastern lobe highlights the continued need to sample this area in years that it is accessible. 


\section{Conclusions}

Our monitoring program has helped to describe sucker population dynamics in the two lakes, but the causes of high apparent first year sucker mortality in Upper Klamath Lake remain unknown. Clear Lake sucker populations are most limited by adult access to spawning habitat, whereas Upper Klamath Lake sucker populations are limited by first year apparent survival (Burdick and Martin, 2017). The timing of spawning and size of the spawning run appears to have a strong influence on the apparent abundance and SL of age-0 suckers in August. Upper Klamath Lake specific stressors, such as poor water-quality and overall high fish density, also may be suppressing growth and survival of age-0 suckers. Differences in the prevalence of afflictions between lakes may offer clues, but more research is required to determine the causes of low sucker survival in Upper Klamath Lake. Lower apparent survival of age-0 Lost River suckers compared to age-0 shortnose suckers in Upper Klamath Lake could be caused by differential survival, emigration, size and age gear selectivity, or a combination of these factors. In 2017 we initiated a study to assess size and age gear selectivity of trap nets for suckers. Determining the primary cause of this taxa specific difference in apparent mortality, could change how Lost River suckers are managed in Upper Klamath Lake.

\section{References Cited}

Banish, N.P., B.J. Adams, R.S. Shively, M.M. Mazur, D.A. Beauchamp, T. M. Wood. 2019.

Distribution and habitat associations of radio-tagged adult Lost River suckers and shortnose suckers in Upper Klamath Lake, Oregon. Transactions of the American Fisheries Society, v. 138, p. 153168.

Barber, I., Hoare, D., and Krause, J., 2000, Effects of parasites on fish behavior-A review and evolutionary perspective: Reviews in Fish Biology and Fisheries, v. 10, p. 131-165.

Barkstedt, J.M., Farrington, M.A., and Kennedy, J.L., 2015, Frequency of opercular deformities in age-0 native catostomids in the San Juan River from 1998 to 2012: Albuquerque, New Mexico, American Southwest Ichthyological Researchers, L.L.C., 38 p.

Barton, B.A., 2002, Stress in Fishes-A diversity of responses with particular references to changes in circulating corticosteroids: Integrative and Comparative Biology, v. 42, p. 517-525.

Beraldo, P., Pinosa, M., Tibaldi, E., and Canavese, B., 2003, Abnormalities of the operculum in gilthead sea bream (Sparus aurata)-Morphological description: Aquaculture (Amsterdam, Netherlands), v. 220, p. 89-99.

Berry, C.R., Jr., Babey, G.J., and Shrader, Terry, 1991, Effect of Lernaea cyprinacea (CrustaceaCopepoda) on stocked rainbow trout (Oncorhynchus mykiss): Journal of Wildlife Diseases, v. 27, p. 206-213.

Boglione, C., Gisbert, E., Gavaia, P., Witten, P.E., Moren, M., Fontagne, S., and Koumoundours, G., 2013, Skeletal anomalies in reared European fish larvae and juveniles - Part 2-Main typologies, occurrences and causative factors: Reviews in Aquaculture, v. 5, no. 1, p. S121-S167.

Bottcher, J.L., and Burdick, S.M., 2010, Temporal and spatial distribution of endangered juvenile Lost River and Shortnose Suckers in relation to environmental variables in Upper Klamath Lake, Oregon - 2009 annual data summary: U.S. Geological Survey Open-File Report 2010-1261, 42 p., https://pubs.usgs.gov/of/2010/1261/.

Buettner, M.E., and Scoppettone, G.G., 1991, Distribution and information on the taxonomic status of the shortnose sucker (Chasmistes brevirostris) and Lost River suckers (Deltistes luxatus) in the Klamath River Basin, California: Reno, Nevada, Seattle National Fishery Research Center, 34 p. Burdick, S.M., Anderson, G.O., and VanderKooi, S.P., 2009, Spring and summer spatial distribution of endangered juvenile Lost River and shortnose suckers in relation to environmental variables in Upper Klamath Lake, Oregon—2007 Annual Report: U.S. Geological Survey Open-File Report 2009-1043, 56 p., https://pubs.usgs.gov/of/2009/1043/. 
Burdick, S.M., and Brown, D.T., 2010, Distribution and condition of larval and juvenile Lost River and shortnose suckers in the Williamson River Delta restoration project and Upper Klamath Lake, Oregon—2009 annual data summary: U.S. Geological Survey Open-File Report 2010-1216, 78 p., https://pubs.usgs.gov/of/2010/1216/.

Burdick, S.M., Dolan-Caret, A., and Martin, B., 2017, Data for trap net captured juvenile Lost River and shortnose suckers from Upper Klamath Lake, Oregon: U.S. Geological Survey Data Release, https://doi.org/10.5066/F7ZC812F

Burdick, S.M., Elliott, D.G., Ostberg, C.O., Conway, C.M., Dolan-Caret, A., Hoy, M.S., Feltz, K.P., and Echols, K.R., 2015, Health and condition of endangered juvenile Lost River and shortnose suckers relative to water quality and fish assemblages in Upper Klamath Lake, Oregon, and Clear Lake Reservoir, California: U.S. Geological Survey Open-File Report 2015-1217, 56 p., 10.3133/ofr20151217.

Burdick, S.M., Hendrixson, H.A., and VanderKooi, S.P., 2008, Age-0 Lost River sucker and shortnose sucker nearshore habitat use in Upper Klamath Lake, Oregon-A patch occupancy approach: Transactions of the American Fisheries Society, v. 137, p. 417-430.

Burdick, S.M., and Hewitt, D.A., 2012, Distribution and condition of young-of-year Lost River and shortnose suckers in the Williamson River Delta restoration project and Upper Klamath Lake, Oregon, 2008-10-Final Report: U.S. Geological Survey Open-File Report 2012-1098, 52 p.

Burdick, S.M., Hewitt, D.A., Rasmussen, J.E., Hayes, B.S., Janney, E.C., and Harris, A.C., 2015, Effects of lake surface elevation on shoreline-spawning Lost River Suckers: North American Journal of Fisheries Management, v. 35, p. 478-490.

Burdick, S.M., and Martin, B.A., 2017, Inter-annual variability in apparent relative production, survival, and growth of juvenile Lost River and shortnose suckers in Upper Klamath Lake, Oregon, 2001-15: U.S. Geological Survey Open-File Report 2017-1069, 55 p., 10.3133/ofr20171069

Burdick, S.M., Ostberg, C.O., Hereford, M.E., and Hoy, M.S., 2016, Juvenile sucker cohort tracking data summary and assessment of monitoring program, 2015: U.S. Geological Survey Open-File Report 2016-1164, 30 p., 10.3133/ofr20161164

Burdick, S.M., and Rasmussen, J., 2012, Preliminary juvenile Lost River and Shortnose Sucker investigations in Clear Lake, California—2011 pilot study summary: U.S. Geological Survey OpenFile Report 2012-1180, 18 p.

Burdick, S.M., and Rasmussen, J., 2013, Age and condition of juvenile catostomids in Clear Lake Reservoir, California: U.S. Geological Survey Open-File Report 2013-1188, 20 p.

Burdick, S.M., and Vanderkooi, S.P., 2010, Temporal and spatial distribution of endangered juvenile Lost River and shortnose suckers in relation to environmental variables in Upper Klamath Lake, Oregon-2008 annual data summary: U.S. Geological Survey Open-File Report 2010-1051, 36 p. Burdick, S.M., Wilkens, A.X., and VanderKooi, S.P., 2008, Near-shore and off-shore habitat use by endangered juvenile Lost River and shortnose suckers in Upper Klamath Lake, Oregon - 2006 data summary: U.S. Geological Survey Open-File Report 2007-1356, 30 p.

Cahu, C., Infante, J.Z., and Takeuchi, T., 2003, Nutritional components affecting skeletal development in fish larvae: Aquaculture (Amsterdam, Netherlands), v. 227, p. 245-258.

Chambers, J.M., Cleveland, W.S., Kleiner, B., and Tukey, P.A., (1983) Graphical Methods for Data Analysis. Wadsworth \& Brooks/Cole. 395p.

Chávez de Martínez, M.C., 1990, Vitamin C requirements of the Mexican native cichlid Cichlasoma urophthalmus (Gunther): Aquaculture (Amsterdam, Netherlands), v. 86, p. 409-416.

Chen, Y., and Harvey, H.H., 1995, Growth, abundance and food supply of white sucker: Transactions of the American Fisheries Society, v. 124, p. 262-271.

Cooperman, M., and Markle, D.F., 2003, Rapid out-migration of Lost River and shortnose sucker larvae from in-river spawning beds to in-lake rearing grounds: Transactions of the American Fisheries Society, v. 132, p. 1,138-1,153. 
Eldridge, D.B., Caldwell Eldridge, S.L., Schenk, L.N., Tanner, D.Q., and Wood, T.M., 2012, Waterquality data from Upper Klamath and Agency Lakes, Oregon, 2009-10: U.S. Geological Survey Open-File Report 2012-1142, 32 p.

Eldridge, S.L.C., Wood, T.M., and Echols, K.R., 2012, Spatial and temporal dynamics of cyanotoxins and their relation to other water quality variables in Upper Klamath Lake, Oregon, 2007-09: U.S. Geological Survey Scientific Investigations Report 2012-5069, 34 p.

Evanno, G., Regnaut, S., and Goudet, J., 2005, Detecting the number of clusters of individuals using the software STRUCTURE-A simulation study: Molecular Ecology, v. 14, p. 2611-2620.

Ferguson, J.A., Koketsu, W., Ninomiya, I., Rossignol, P.A., Jacobson, K.C., and Kent, M.L., 2011, Mortality of coho salmon (Oncorhynchus kisutch) associated with burdens of multiple parasite species: International Journal for Parasitology, v. 41, no. 9, p. 1197-1205.

Galeotti, M., Beraldo, P., de Dominis, D., D’Angelo, L., Ballestrazzi, R., Musetti, R., Pizzolito, S., and Pinosa, M., 2000, A preliminary histological and ultrastructural study of opercular anomalies in gilthead sea bream larvae (Sparus aurata): Fish Physiology and Biochemistry, v. 22, p. 151-157.

Hamley, J.M., and Regier, H.A., 1973, Direct estimates of gillnet selectivity to walleye (Stizostedion vitreum vitreum): Journal of the Fisheries Research Board of Canada, v. 30, p. 817-830.

Hendrixson, H.A., Burdick, S.M., VanderKooi, S.P., and Wilkens, A.X., 2007, Near-shore and offshore habitat use by endangered, juvenile Lost River and shortnose suckers, and near-shore water quality, in Upper Klamath Lake, Oregon-Annual report 2004: Report of U.S. Geological Survey, Western Fisheries Research Center, Klamath Falls Field Station to the Bureau of Reclamation, MidPacific Region, Klamath Falls, Oregon.

Hewitt, D.A., and Hayes, B.S., 2013, Monitoring of adult Lost River and shortnose suckers in Clear Lake Reservoir, California, 2008-2010: U.S. Geological Survey Open-File Report 2013-1301, 18 p., 10.3133/ofr20131301

Hewitt, D.A., Janney, E.C., Hayes, B.S., and Harris, A.C., 2015, Status and trends of adult Lost River (Deltistes luxatus) and shortnose (Chasmistes brevirostris) sucker populations in Upper Klamath Lake, Oregon, 2014: U.S. Geological Survey Open-File Report 2015-1189, 36 p., 10.3133/ofr20151189

Hollander, M., and Wolfe, D.A., 1973, Nonparametric Statistical Methods: New York, John Wiley \& Sons, p. 115-120.

Hoy, M.S., and Ostberg, C.O., 2015, Development of 20 TaqMan assays differentiating the endangered shortnose and Lost River suckers: Conservation Genetics Resources, v. 7, no. 3, p. 673 676. 10.1007/s12686-015-0474-y

Kelly, D.W., Patterson, R.A., Townsend, C.R., Poulin, R., and Tompkins, D.M., 2009, Parasite spillback-A neglected concept in invasion ecology?: Ecology, v. 90, no. 8, p. 2047-2056.

Kent, M., Markle, D.F., Terwilliger, M., and Simon, D.C., 2014, Chapter 4 Pathogen investigation of Upper Klamath Lake fishes with emphasis on suckers. page 123-172 in Larval and Juvenile Ecology of Upper Klamath Lake Suckers:2009-2013 Final Report for Agreement R09AC20029. Simon, D.C., Terwilliger, M. R., and Markle, D. F. editors. 172 p.

Kent, M.L., Janick, A., Tkach, V.V., Choudhury, A., and Peterson, J.T., 2017, Describing the Potential Predator Field of Young Suckers in Upper Klamath Lake-Parasites. Final Report under Agreement R15PG00073. Oregon State University, 36 p.

Lall, S.P., 2002, The minerals, in Halver, J.E., and Hardy, R.W., Fish Nutrition 3rd ed.: San Francisco, Academic Press, p. 259-308.

Lehmann, E.L., 1986, Testing Statistical Hypotheses (second edition). Wadsworth and Brooks/Cole, Pacific Grove, California

National Marine Fisheries Service and U.S. Fish and Wildlife Service, 2013, Biological Opinions on the Effects of Proposed Klamath Project Operations, from May 31, 2013 through March 31, 2023, on Five Federally Listed Threatened and Endangered Species U.S. Fish and Wildlife Service: Sacramento, California, Pacific Southwest Region, 607 p. 
National Research Council, 2004, Endangered and threatened fishes in the Klamath River BasinCauses of decline and strategies for recovery: Washington, D.C., The National Academies Press, 398 p.

Markle, D.F., Cavalluzzi, M.R., and Simon, D.C., 2005, Morphology and taxonomy of Klamath basin suckers (Catostomidae): Western North American Naturalist, v. 65, no. 4, p. 473-489.

Markle, D.F., Terwilliger, M.R., and Simon, D.C., 2014, Estimates of daily mortality from Neascus trematode in age-0 Shortnose Sucker (Chasmistes brevirostris) and the potential impact of avian predation: Environmental Biology of Fishes, v. 97, p. 197-207.

Pritchard, J.K., Stephens, M., and Donnelly, P., 2000, Inference of population structure using multilocus genotype data: Genetics, v. 155, p. 945-959.

Quist, M.C., Pegg, M.A., and DeVries, E.R., 2012, Age and Growth in Zale, A.V., Parrish, D.L., Sutton, T.M., and Sutton, T.M., Fisheries Techniques 3rd ed.: Bethesda, Maryland, American Fisheries Society, p. 223-266.

R Core Team, 2013, R-A language and environment for statistical computing: Vienna, Austria, R Foundation for Statistical Computing, ISBN 3-900051-07-0, http://www.R-project.

Robinson, A.T., and Childs, M.R., 2001, Juvenile growth of native fishes in the Little Colorado River and in a thermally modified portion of the Colorado River: North American Journal of Fisheries Management, v. 21, p. 80-815.

Scoppettone, G. G., and G. Vinyard, 1991, Chapter 18: life history and management of four endangered, in lacustrine suckers. Battle Against Extinction: Native Fish Management in the American West. Editors W.L. Minckley and J. E. Deacon. University of Arizona Press, Tucson, AZ. Simon, D., Terwilliger, M.R., and Markle, D.F., 2013, Annual report for project, larval and juvenile ecology of Upper Klamath Lake suckers-2012: Oregon State University Report to Bureau of Reclamation, $88 \mathrm{p}$.

Stauffer-Olsen, N.J., Carter, J.L., and Fend, S.V., 2017, Spatial and temporal variability in benthic invertebrate assemblages in Upper Klamath Lake, Oregon: Northwest Science, v. 91, no. 3, p. $257-$ 271.

Sutphin, Z., and Tyler, T., 2016, Entrainment of early life-stage of fish from Clear Lake Reservoir into Lost River. Bureau of Reclamation, $25 \mathrm{p}$.

Tringali, M.D., Ziemann, D.A., and Stuck, K.C., 2001, Preliminary aspects of genetic management for Pacific Threadfin Polydactylus sexfilis stock enhancement research in Hawaii, in Nakamura, Y., McVey, J.P., Leber, K., Neidig, C., Fox, S., and Churchill, K., eds., Ecology of aquaculture species and enhancement of stocks, Proceedings of the U.S.-Japan Meeting on Aquaculture, 30th, December 3-4, 2001, Sarasota, Florida: Cooperative Program in Natural Resources (UJNR) Technical Report, no. 30 , p. $55-74$.

U.S. Fish and Wildlife Service, 1988, Endangered and threatened wildlife and plants-Determination of the Status for the Shortnose Sucker and Lost River Sucker: Federal Register, v. 53, no. 137, p. $27130-27134$.

U.S. Fish and Wildlife Service, 2013, Revised recovery plan for the Lost River Sucker (Deltistes luxatus) and Shortnose Sucker (Chasmistes brevirostris): U.S. Fish and Wildlife Service, Pacific Southwest Region, Sacramento, California. xviii +122 p.

Winemiller, K.O., and Taylor, D.H., 1982, Inbreeding depression in the convict cichlid Cichlosoma nigrofasciatum (Baird and Girard): Journal of Fish Biology, v. 21, p. 399-402. 

Publishing support provided by the U.S. Geological Survey

Science Publishing Network, Tacoma Publishing Service Center

For more information concerning the research in this report, contact the Director, Western Fisheries Research Center

U.S. Geological Survey

6505 NE 65th Street

Seattle, Washington 98115

https://wfrc.usgs.gov/ 


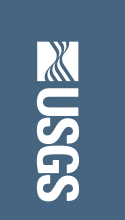

몰

产

웅

施

5

蛋

言

总

\&

产

돟

증

产

옹

言

오

$\frac{\sqrt{9}}{\frac{9}{7}}$

䎡

俤

윽

蕞

突

$\widetilde{\Xi}$

중

홈

㞼

I

ISSN 2331-1258 (online) 